\title{
Cooptation in Practice: Measuring Legislative Opposition in an Authoritarian Regime
}

\author{
Daniel L. Tavana* \\ daniel.tavana@yale.edu
}

\author{
Erin York ${ }^{\dagger}$ \\ eay2109@columbia.edu
}

First version: November 30, 2020

This version: November 30, 2020

\begin{abstract}
Canonical theories of legislative institutions in authoritarian regimes highlight the role of oppositions in legitimizing non-democratic rule, shaping the autocrat's policy agenda, and extracting concessions. Despite recent advances in understanding how oppositions shape larger, macro-level outcomes, surprisingly little attention has been given to the question of how legislators behave in office and how the regime manages potential opposition. In this paper, we construct a novel dataset of roll call vote records spanning the entirety of Kuwaiti legislative history-more than 150,000 votes over 53 years. We use this to develop a new method for measuring legislative opposition to and cooperation with an authoritarian regime on substantive policy issues. We then test the effectiveness of regime strategies - rents and policy concessions-for coopting potential opposition and examine the circumstances under which these these strategies are used 11
\end{abstract}

Keywords: authoritarian regimes; roll call voting; Middle East; Kuwait; opposition; legislature; cooptation

${ }^{*}$ Postdoctoral Fellow, Council on Middle East Studies, Yale University.

${ }^{\dagger}$ Postdoctoral Fellow, Niehaus Center for Globalization and Governance, Princeton University.

1 Support for this research was provided by the Mamdouha S. Bobst Center for Peace and Justice and the Department of Politics at Princeton University. We thank Monia Bsat and Lebanon Support for their partnership in the data collection process and Marwa Ammar for her research assistance. Our gratitude goes to Abdullah Alkhonaini, Ala' Alrababa'h, Quintin Beazer, Jason Brownlee, Reva Dhingra, Nate Grubman, Allison Hartnett, Holger Kern, Tahir Kilavuz, Steve Monroe, Biff Parker-Magyar, Christiana Parreira, Paul Schuler, Eoghan Stafford, Scott Williamson, and Kadir Yildirim for helpful comments at various stages of the project. This article benefitted from presentations and helpful feedback at the Middle East Initiative (MEI) Fellows workshop at the Harvard Kennedy School of Government, the Virtual Workshop on Authoritarian Regimes (VWAR), and the Vanderbilt Department of Political Science Faculty Workshop. Any remaining errors are our own. 


\section{Introduction}

How do autocrats use electoral and legislative institutions to coopt potential challengers? Foundational work in comparative politics considers the central political conflict in autocracy to be one between a small group of autocratic elites and the much larger population over which it rules. Autocrats endeavor to resolve this conflict in one of two ways Wintrobe 1998; Svolik 2012. They may rely on repression, or "the actual or threatened use of physical sanctions against an individual or organization" Davenport 2007. Alternatively, they may rely on cooptation, or the intentional exchange of economic rents or policy concessions to rival elites in exchange for compliance with the autocrat's policy agenda.

Research on autocracy has generated a number of plausible explanations for how electoral and legislative institutions facilitate cooptation. The logic of cooptation theory emphasizes the importance of eliciting loyalty from a broader class of actors for regime survival. Instead of repressing these actors, regimes often permit a limited form of political competition. Electoral and legislative institutions - with less political authority but otherwise similar to their democratic counterpartsinstitutionalize the regime's relationship to these actors and manage their access to the regime. Today, most authoritarian regimes host elected legislatures with lawmaking power.

Despite the ubiquity of electoral and legislative institutions under autocracy, there is much that is poorly understood about the mechanisms that facilitate cooptation in these institutions. A key puzzle remains: once it has established a legislature and granted it law-making power, how does an autocrat ensure that those elected will cooperate with its policy agenda? In a seminal paper, Gandhi \& Przeworski 2006 outline two regime strategies for soliciting cooperation: policy concessions and rents. Though they offer theoretically robust explanations for the use of these two strategies, a strong empirical test of their arguments has not been conducted. This is due primarily to data limitations, the difficulty inherent in the measurement of cooperation, and the private nature of elite exchange in authoritarian contexts.

In this paper, we present a novel set of comprehensive historical data on legislative behavior in Kuwait. We use these data to create a unique measure of cooperation with the regime and develop tests that assess the fundamental principles of cooptation. Do longstanding strategic mechanisms common in cooptation theory - rents and policy concessions - effectively increase cooperation with 
incumbent autocrats? Are these strategic mechanisms substitutable?

To answer these questions, we collect roll call votes on all successful legislation in Kuwaiti legislative history, totaling more than 150,000 individual votes across over 3,000 laws passed from 1963 to 2016. These data cover fifteen legislative terms and represent the most comprehensive dataset of this kind from within an autocracy. We use these data to establish a new measure of cooperation with the regime agenda on policy issues and demonstrate its validity. We then test whether the proposed mechanisms - rents and policy-related concessions - predict cooperation with the regime on individual legislation. We next turn our attention to the regime's strategic behavior, examining when it is more likely to use rents versus policy concessions, and which actors these strategic mechanisms can be deployed to effectively coopt.

This research adds to a growing body of research investigating the internal workings of authoritarian institutions, particularly as new sources of data emerge from within these regimes Gandhi et al. 2020. . Though previous scholarship often described these institutions as "rubber stamp" bodies that served the personal whims of dictators Brancati 2014, researchers are increasingly recognizing the importance of these institutions in responding to citizen needs Distelhorst \& Hou 2017), representing citizen interests on non-sensitive issues (Truex 2016), and moderating protest and dissent Reuter \& Robertson 2015. Yet the particular dynamic we study here - substantive support for and opposition to the regime's policy agenda - is novel both for the comprehensiveness of the data used, covering the entirety of Kuwaiti legislative history, and the unique level of insight into both the behavior of the regime and those elected into office. This offers a new and vastly more precise look into the internal workings of autocratic legislatures.

\section{Cooptation Theory and Strategic Mechanisms}

In response to the growing number of hybrid regimes globally, scholars have generated several explanations for why autocrats establish electoral and legislative institutions. These include arguments that such institutions allow autocrats to gather information about public opinion, enhance regime legitimacy both domestically and internationally, and distribute responsibility for citizen welfare among a broader class of political actors. Most prominent among these explanations is cooptation theory. Broadly, cooptation is a process through which incumbent autocrats induce conformity 
toward the consensus of a ruling coalition's executive elites Stacher 2012, pp. 112). We propose a more narrow definition of cooptation as the intentional exchange of economic rents or policy concessions to rival elites in exchange for compliance with the autocrat's policy agenda.2 In the remainder of this section, we review the literature on cooptation theory, address a key shortcoming of existing studies, and present a set of hypotheses subsequent sections will evaluate.

In a seminal study, Gandhi \& Przeworski 2006 propose two distinct mechanisms through which cooptation induces cooperation: rents (direct payments to rival elites) and policy concessions. Though they offer clear theoretical predictions, Gandhi \& Przeworski lack a strong empirical test of their argument. In particular, they treat the mere existence of legislatures and political parties as evidence of cooptation $3^{3}$ The presence of a competitive legislature provides an opportunity for cooptation, but there is less clarity on when and how it takes place. We propose that these legislatures represent plausible evidence of cooptative behavior, but that it is within these bodies that the regime engages in the more narrowly specified cooptative process defined above. That is to say, first, the regime establishes competitive institutions, and subsequently it engages in cooptative behavior with participants in these institutions. Our goal here is to elaborate on and identify the nature of the exchanges between the regime and legislative actors.

We propose that the regime offers both rents and policy concessions in exchange for legislative cooperation, conditional on its own preferences and those of the legislative actors it seeks to buy off. We are not the first to point out that rents are distributed to legislative participants; as Blaydes 2011 and others argue, candidates in autocratic elections compete for access to a variety of perks exclusive to elected positions, including business opportunities and personal payments. But these are not the only benefits of office, and candidates differ in how they value these opportunities. Some candidates may be office-seeking, interested merely in the personal perks from gaining access to power, while others run to gain opportunities to extract policy concessions from the regime $4^{4}$

\footnotetext{
${ }^{2}$ We borrow here from Frantz \& Kendall-Taylor 2014 pp. 333), who define cooptation as "the intentional extension of benefits to potential challengers to the regime in exchange for their loyalty" (pp. 333). In addition, we borrow from Gandhi \& Przeworski 2006 pp. 2) who argue that autocrats have "two instruments to mobilize cooperation and to prevent rebellion: policy concessions and distribution of rents."

${ }^{3}$ Other subsequent studies make a similar assumption. For example, Gandhi 2008 pp. 92) Jensen et al. 2014, and Frantz \& Kendall-Taylor 2014 measures the degree of cooptation by counting the number of political parties that exist in a given legislature.

${ }^{4}$ We intend for the "office-seeking" and "policy-seeking" labels to refer to archetypes along a spectrum. In practice, individual politicians value both types of concessions and the degree to which they are more or less policy-seeking is a matter of the relative weight they apply to each type.
} 
The distribution of candidates (who runs) will in general be endogenous to the institutional setting and the goods available. For example, in polities where the legislature has comparatively little political authority, we might expect fewer candidates that prioritize policy concessions, as these would be harder to extract in such a setting.5 In the context we examine here, both rents and policy concessions are plausible benefits of office and both candidate types are represented in the Kuwaiti legislature, as evidenced by the participation of members of ideological blocs (see section 4.3 in addition to regime insiders such as former oil executives.

Recent studies have uncovered the "micrologic" of cooptation by evaluating the nature of deputy behavior in these contexts and uncovering the mechanisms that produce cooperation. But these studies have tended to focus on less costly mechanisms of legislator influence, such as amendments (Noble 2018), query sessions Malesky \& Schuler 2010, and committee assignments Reuter \& Robertson 2015.

\subsection{The logic of within-legislature cooptation}

Autocratic regimes may make use of a number of electoral manipulations (including banning or restricting certain parties or actors, manipulating districts and voting rules, etc.) to ensure that most of the legislators that are elected are friendly to its cause. But once elections have been held at the beginning of a term, the set of players in the legislative bargaining game is established. At this point, the regime must find a way to induce cooperation among deputies present in the legislature.

Legislatures contain a diverse set of deputies with varying demand for the different perks that the regime is equipped to provide (rents and policy concessions). Though the balance of power in such settings is skewed in favor of the autocrat, the fact that legislative approval is required to pass new laws gives individual deputies some bargaining power relative to the regime. The regime thus needs to purchase the cooperation of actors within the assembly to ensure its policy agenda is enacted. Some elected politicians are more amenable to this prospect than others, and their cooperation may be cheaper (or costless) to obtain.

The regime has at its disposal both carrots and sticks to control the legislature within a given term. Among the latter, we would include executive authorities such as the ability to dissolve

\footnotetext{
${ }^{5}$ The Egyptian legislature that Blaydes 2011 characterizes may be one example of a legislative body where there are few opportunities for policy-seeking actors and where we would correspondingly expect comparatively fewer of them to seek office.
} 
a legislature or declare a state of emergency as well as vetoes and executive orders that may supersede laws passed. But in practice, these 'sticks' may be costly to employ-if overly public, they may threaten regime legitimacy both domestically and internationally. In such cases, it may be preferable to the regime to stick with carrots: the economic rents and policy concessions that, if cleverly deployed, ensure that the legislature cooperates with the autocrat's policy agenda ${ }^{6}$

In the real world of authoritarian policymaking, it is difficult to assess the relative importance of economic rents and policy concessions for a variety of reasons. First, data from these legislatures is often not made public and almost always difficult to obtain. Few autocracies publish data on the activities of individual deputies and their degree of cooperation with or opposition to incumbent autocrats. Even where data on legislative behavior is available, there is a second challenge to the empirical assessment of cooptation: uncertainty about the underlying preferences of legislative deputies and lack of visibility into regime offers. Due to the sensitive nature of these exchanges, both autocrats and deputies have incentives to conceal their preferences and the nature of their interactions from the public. Legislators and autocrats do not publicly disclose when rents or concessions have been exchanged for cooperation. In practice, we may only observe whether a deputy supports the regime agenda (successful cooptation) or opposes it (failure).

Though we cannot observe either a deputy's private preference or the processes that precede a deputy's public behavior, we instead propose that, consistent with cooptation theory, changes in an autocrat's use of economic rents and policy concessions can allow us to empirically assess whether or not cooptation effectively induces cooperation. To do so, we focus on the use and effect of these mechanisms on deputy cooperation within a legislature. Our first two hypotheses spell out the purported efficacy of these two mechanisms. First, we consider the effect of economic rents on cooperation with the autocrat's policy agenda. Here, we are interested in the marginal value of cash to the regime, rather than the actual distribution or provision of economic rents to individual deputies:

$H_{1}$ : More rents available to the regime will be associated with greater cooperation with the autocrat's policy agenda.

\footnotetext{
${ }^{6}$ Note that even in cases where policies are not at risk of failure to pass, there is reason to expect the regime to buy added support so as to give its policies a stronger mandate in the public eye. In other words, while the regime may require majority support to minimally satisfy its policy objectives, its utility may be increasing in the level of support.
} 
Second, we consider the effect of policy concessions on cooperation with the autocrat's policy agenda:

$\mathrm{H}_{2}$ : Evidence of policy concessions granted to legislators will be associated with greater cooperation with the autocrat's policy agenda.

These two hypotheses link regime strategies to behavior within the legislature. We further argue that legislative 'type' influences the marginal effectiveness of these strategies. That is to say, these two strategic mechanisms will be differentially effective in inducing cooperation among different types of deputies because they place differing weights on each type of concession. For rent-seeking deputies, we expect that policy concessions are of little interest.7 Correspondingly, we expect that for policy-seeking deputies, rent concessions are of lower marginal utility. We thus expect policy-seeking deputies to exhibit greater levels of cooperation when the autocrat makes greater use of policy concessions vis-a-vis economic rents (and vice versa).

$H_{3}$ : When more (fewer) rents are available, less (more) ideological politicians will be most likely to be coopted.

\section{Context}

\subsection{Background: Kuwait National Assembly}

Scholars of the Middle East view the Kuwait National Assembly (KNA) as the strongest legislative institution among the autocratic Gulf Cooperation Council (GCC) countries, if not the entire Arab World Zaccara 2013 Shalaby 2015 Freer 2018 8 The 1962 Constitution establishes a political system described as "a hereditary Emirate held in succession in the descendants of Mubarak AlSabah," (Article 4) with a "separation and cooperation of powers" between the executive and legislative branches (Article 50). Executive power is vested in the Emir, who appoints a prime minister and approves his Council of Ministers (cabinet). Legislative power is vested in both the

\footnotetext{
${ }^{7}$ However, because deputies that we classify as 'rent-seeking' also have no publicly stated ideological preferences, we are also hampered in testing this expectation empirically.

${ }^{8}$ The causal origin of legislative strength in Kuwait is the subject of considerable scholarly debate. Explanations include the existence of a politically assertive merchant class before the discovery of oil Crystal 1995 Salih 1992

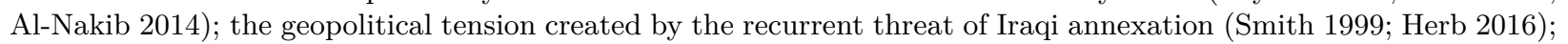
and on more equitable indigenous institutions, particularly the historical role of the Emir as primus inter pares [first among equals] Zahlan 1998 Longva 1999.
} 
Emir and the National Assembly (Article 51). Kuwait resembles other hybrid regimes with elected legislatures and unelected, or hereditary, executives, with one key exception. After the investiture of a new Emir, the National Assembly must, by majority vote, approve his choice of Crown Prince. Kuwait epitomizes constitutional monarchism, with the exception that the Emir - rather than the legislature - retains the right to appoint the prime minister and cabinet. In this sense, Kuwait is "neither an archetypal hereditary emirate nor a full-fledged pluralistic polity" Ulrichsen 2014 pp. 229).

The KNA is a unicameral body with fifty members elected by secret ballot every four years across five electoral districts. In addition to the fifty legislators, ministers (members of the Council of Ministers) serve as ex officio, voting members of the legislature. Ministers may include members of the ruling Al-Sabah family, elected members of the KNA, and others outside government. The total number of ministers may not exceed one-third the number of elected members of the KNA, or sixteen 9 After appointing a prime minister, the Emir retains the discretionary power to appoint ministers and relieve them from their posts.

Most legislation in the National Assembly originates with the Council of Ministers. At the beginning of each annual session, the government presents its own legislative agenda and offers a tentative schedule of draft laws. Each of these draft laws must be processed through a particular legislative committee before the draft law can be brought to the Assembly floor. In practice, this means that the Council of Ministers must work closely with elected deputies to ensure its draft laws pass. Any given law requires the support of at least 18 to 19 elected deputies (in addition to members of the Council of Ministers). The Prime Minister-working through the Council of Ministers - works actively to persuade deputies to support these laws.

Though the Prime Minister and Council of Ministers exert a significant degree of control over legislative activity, the Constitution endows the Assembly with considerable supervisory power. At any time, a majority of elected deputies can interpellate individual ministers or the prime minister himself Herb 2016). Since 1963, the threat of interpellation has allowed the National Assembly a degree of influence over government policy. Salih 2006 pp. 39) summarizes this point succinctly: "The possibility or even implicit threat of the use of the no-confidence vote is more important

\footnotetext{
${ }^{9}$ The size of the cabinet is up to the emir, but in practice, it is typically composed of exactly sixteen ministers- the maximum number allowed - and has never been smaller than twelve ministers (on one occasion in 1971 and another in 1996).
} 
than its actual use." As the Council of Ministers endeavors to win votes from elected deputies, it adjusts policy accordingly. These legislative dynamics underscore the Assembly's autonomy the and strategic interaction that takes place between elected deputies and the government.

The threat of interpellation has been a durable source of legislative gridlock in the National Assembly. Critics allege that, in the post-liberation period, the threat of interpellation has been abused, initiated more often to settle personal rivalries and draw attention to marginal issues Salih 2006. The escalatory nature of these interpellations - and the heightened political nature of their use - has often led to the dissolution of the Assembly itself. At any time, the Emir can dissolve the Assembly, provided new elections are held within 60 days. Since the restoration of the Assembly in 1992, only two assemblies have run out their full four-year terms. In the past two decades, there have been nine elections.

\subsection{Political Cleavages in Kuwait}

Kuwait is a communally diverse autocracy, and electoral competition occurs between discrete groups. Group membership is defined by sect (Sunna and Shia) and origin. The salience of origin is rooted in the patterns of migration that contributed to the city's rise as a thriving commercial settlement. Kuwait City was established in the 18th century, when a group of families known collectively as the Bani 'Utub migrated from Najd, in present-day Saudi Arabia, to Kuwait. Over time, these families were joined by other migrant families from Iran, Iraq, and elsewhere in Saudi Arabia and along the Gulf littoral. Continuous immigration was key to Kuwait's growth and expansion: "the more inhabitants there were, the larger was the labor force, and the more Kuwaiti vessels could participate in trading, shipping, and pearling" Al-Nakib 2016 pp. 27). These families gradually urbanized and integrated themselves into the local economy.

Beginning in the 1960s, the leaders of the newly independent state began settling sedentarizing Bedouin ( $b a d u$ ) who lived in shantytowns throughout the city's environs. These tribespeople were largely relegated to new, large housing projects outside the city. At the same time, the ruling family moved to provide badu with citizenship and access to the state: from 1960 to 1980, hundreds of thousands of tribespeople were naturalized, nearly tripling the citizen population from 200,000 to 600,000 Assiri 1990 Ghabra 1997b Beaugrand 2017. Like those who migrated to Kuwait, these tribes were not "native" to Kuwait City: they could trace their lineage back to various Northern 
and Southern Arabian tribes.

These social cleavages combine to divide the country into discrete groups defined by origin and sect. These groups include urban Sunna and Shia families who trace their origins to their ancestors' settlement in Kuwait City in the pre-oil era, and several previously nomadic tribes - of varying size — whose ancestors were naturalized after independence. These group affiliations persist to this day.

Religion and origin shape the communal attachments that organize both social and electoral life in Kuwait. But so, too, do various ideological forces. National-liberal and Islamist political associations proliferated in Kuwait even before independence. In many ways, the strength and resilience of the KNA is itself a product of the diversity of civic and associational life. As a result, Kuwait boasts "the most vociferous and powerful system of political participation among the six Gulf States" Baaklini et al. 1999, pp. 216). These associations have been active since the first National Assembly elections were held in 1963.

Despite the diversity of civic and associational life in Kuwait, institutionalized political parties do not exist. Although there is no formal ban on political parties, there is no law establishing formal political parties and, since independence, the ruling family has actively discouraged the formation of party organizations. As a result, over time, various political associations and organizations have developed into what Kraetzschmar 2018 describes as "proto-parties." The extent to which these groups play a gatekeeping function varies considerably. In some cases, they officially nominate candidates and choose individuals from among their membership to run in a given district. In other cases, they endorse like-minded independent candidates, limiting the number of official candidates to a few. Though the strength and popularity of these parties has varied over time, generally, they have fallen into one of six camps: national-liberal, Muslim Brotherhood, Salafi, independent Islamist, Shia Islamist and, more recently, leftist-populist. We discuss these blocs in more detail in section 4.3 below. 
Table 1: MP and Minister Characteristics, 1963-2016

\begin{tabular}{lcc}
\hline \hline & Elected Deputies & Ministers \\
Age (mean) & 46.5 & 49.1 \\
Female & 0.01 & 0.04 \\
Education: Known & 0.72 & 0.82 \\
$\quad$ Secondary & 0.26 & 0.19 \\
$\quad$ Bachelor & 0.46 & 0.47 \\
$\quad$ Post-graduate & 0.28 & 0.34 \\
Ideological Affiliation & & \\
$\quad$ None & 0.62 & 0.79 \\
$\quad$ National Liberal & 0.14 & 0.07 \\
$\quad$ Left-Populist & 0.03 & 0.00 \\
$\quad$ Muslim Brotherhood & 0.05 & 0.07 \\
$\quad$ Salafi & 0.05 & 0.03 \\
$\quad$ Ind. Islamist & 0.07 & 0.03 \\
$\quad$ Shia Islamist & 0.04 & 0.01 \\
Tribal Affiliation & 0.48 & 0.13 \\
Shia & 0.14 & 0.08 \\
Al-Sabah & 0 & 0.32 \\
\hline Observations & 786 & 331 \\
\hline
\end{tabular}

Note: Table compares demographic attributes of MPs and ministers represented in the KNA through 2016. The unit of analysis is the individualterm level (meaning deputies elected to multiple terms appear multiple times in the dataset). Age is represented as a numeric mean based on the individual's age at the time he took office; all other attributes are represented in proportional terms. Al-Sabah indicates a member of the ruling family. Source: Kuwait National Assembly Roll Call Votes (KNA-RCV) dataset.

In general, the Kuwaiti government incorporates a diverse (though not necessarily representative) range of individuals. Table 1 presents descriptive statistics on elected MPs and appointed ministers through 2016. Both deputies and ministers are relatively well-educated with a majority attaining undergraduate or post-graduate degrees, many from western universities. The KNA also incorporates Kuwait's social and political groups; notably, both ethnoreligious and ideological groups are better represented in the assembly than among cabinet ministers. Women, on the other hand, are nearly absent from both bodies ${ }^{10}$ Both MPs and ministers reveal a diverse set of occupational backgrounds (Figure 1). Unsurprisingly given Kuwaiti employment patterns, public sector careers are the most common. Yet around half of MPs were otherwise employed, coming to the KNA from the private sector, academia, or other careers including medicine and media.

\footnotetext{
${ }^{10}$ Women were not given the right to vote or run for office until 2005.
} 
Collectively, these statistics confirm that the KNA is a relatively diverse institution incorporating ideologically-oriented individuals as well as a range of other business and occupational sectors.

Figure 1: Occupational Backgrounds of Kuwaiti Ministers and MPs

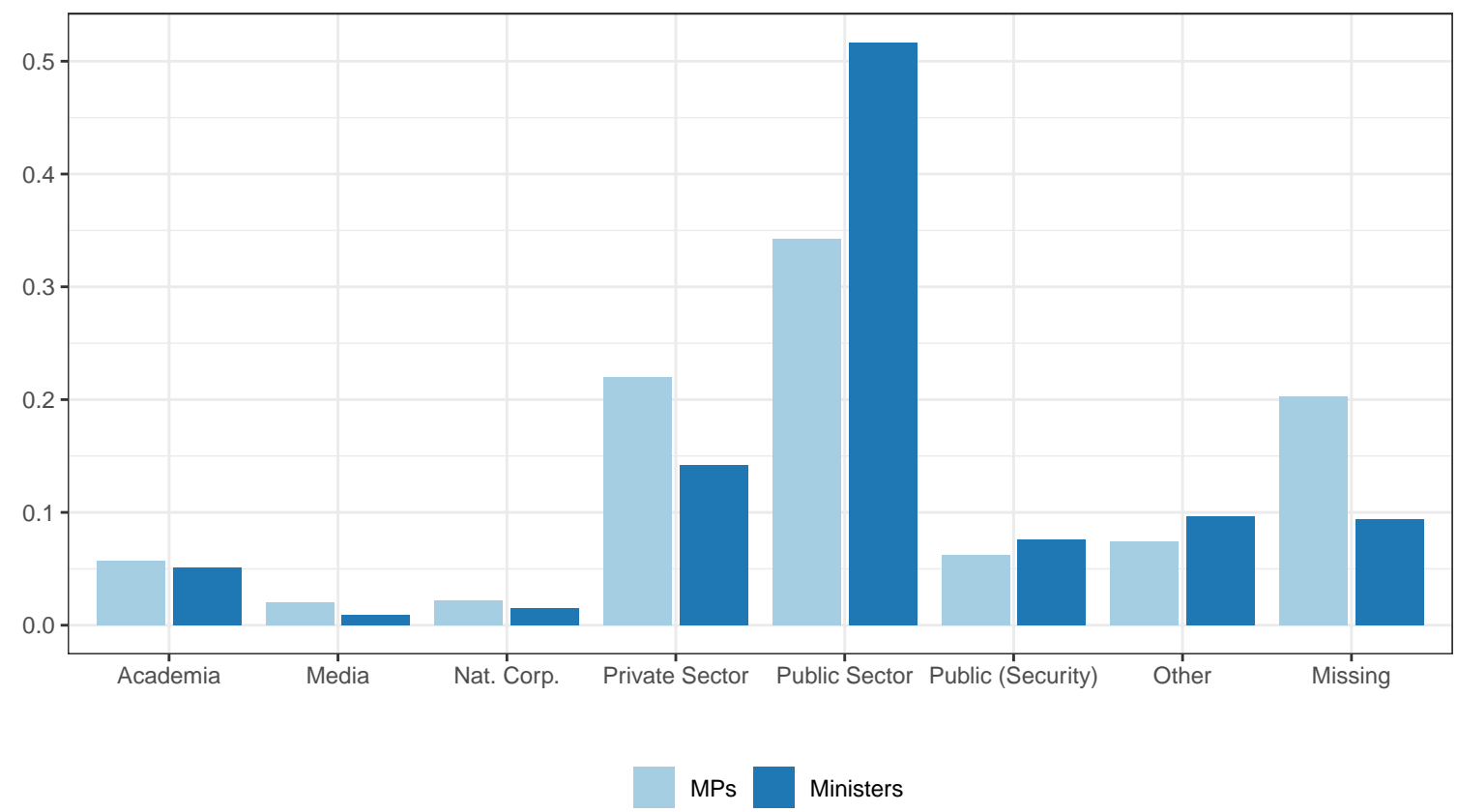

Note: Primary occupational background of ministers and MPs represented in the KNA or Council of Ministers between 1963 and 2016. Proportions are calculated at the individual-term level ( $\mathrm{N}$ of 786 MPs and 331 ministers). National corporation category includes the Kuwait Petroleum Corporation and Kuwait Airways. Source: Kuwait National Assembly Roll Call Votes (KNA-RCV) dataset.

\subsection{Legislative Procedure and Policymaking in the KNA}

Scholars of Kuwaiti politics view the KNA as providing input into an Al-Sabah-dominated policy process in two important ways. First, the ruling family can use the panoply of social and ideological forces in the KNA against each other in an effort to ensure balance. This prevents any one group from obtaining too much power and threatening the regime itself - effectively a divide-and-rule strategy designed to ensure social peace Azoulay 2015 Allarakia 2016 and similar to autocratic approaches in other contexts. Second, the KNA encourages an indigenous spirit of consultation underwritten by the constitutional requirement that all laws and decrees must be approved by the body Khalaf 1984, Tetreault 1991). This is not to suggest that there is no conflict in the KNA - there is. But legislators and ministers must work together in order to approve legislation. 
Generally, there are six mechanisms through which deputies can exert direct and indirect influence on government policy: voting, recommendations, questions, debates on current issues, investigative committees, and interpellation. In this article, we focus on voting and the process through which laws are approved. Though each of these mechanisms is important, we focus on legislation because it has the most explicit policy implications. The government may respond to recommendations, provide answers to deputy questions, and participate in debates and investigations. But only successful legislation compels the government to pursue a particular course of action.

The lawmaking process proceeds in three stages: submission, committee evaluation, and full assembly deliberation 11 In the first stage, submission, individual legislators or the Council of Ministers prepare to submit a law to the speaker of the National Assembly. Laws originating with the Council of Ministers are referred to as draft laws (mashrü $\bar{a} t b i$-qānūn). Laws originating with

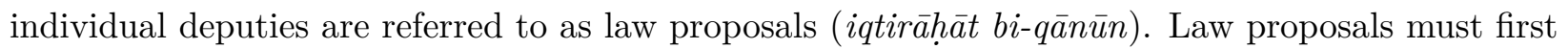
be reviewed by the Legislative and Legal Affairs Committee (Lajnat al-Shu'ūn al-Tashrìiyya wa al-Qānūniyya), which reviews the proposal for legal suitability. After law proposals are approved by the Legislative and Legal Affairs Committee, they are sent back to the speaker. Generally, it is assumed that draft laws submitted by the Council of Ministers have already been reviewed by capable government lawyers, and do not need to pass through the Legislative and Legal Affairs Committee.

Next, standing committees evaluate both draft laws and law proposals by reviewing and reporting on these submissions. Once draft laws and law proposals reach the speaker of the KNA, they are sent - at the speaker's discretion - to one of eight standing committees. Each committee consists of five to nine elected deputies. Once a draft law or law proposal reaches a committee, the committee may hold meetings to discuss the law and propose and approve amendments. After deliberation, the committee submits the original draft, proposed amendments, and a summary report back to the speaker. Draft laws can stay in committees for as long as the Council of Ministers would like. Law proposals, however, become void when the assembly term ends or when the assembly is dissolved.

Last, the speaker prepares the law (along with the committee report) for the full assembly's

\footnotetext{
${ }^{11}$ Provisions of the 1962 Constitution outline the separation of powers between the Emir, the National Assembly, and the Judiciary. More detailed procedural concerns are laid out in Law No. 12 of 1963 on the Internal Regulations

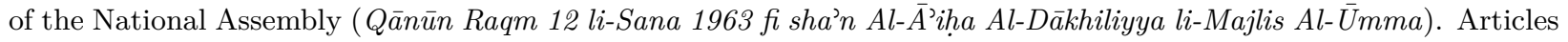
97-110 describe the processes and rules governing the legislative process.
} 
deliberation. The speaker introduces the original draft, committee report, and committee amendments. An initial vote is then held on whether or not to discuss the law "in principle." Then, the full assembly votes on each amendment presented by the standing committee. At the conclusion of this process, a second vote - known as the "first deliberation"-is held on whether or not to advance the law forward. Once the first deliberation is approved, all deputies are permitted to submit amendments. At the conclusion of this process, the assembly takes its third and final vote on the law: the "second deliberation." The second deliberation must take place at least four days after the first deliberation ${ }^{12}$ If the Assembly approves the law on the second deliberation, it is sent to the Emir for approval. The second deliberation thus stands as the final word on a given piece of legislation and the stage at which voting decisions have the most direct and immediate policy implications.

Perhaps the most unique feature of the legislative process is the presence of ministers (members of the Council of Ministers) as ex officio, voting members in assembly deliberations. The legislative prerogatives of the Council of Ministers shape legislative activity and compel ministers to work with elected deputies in an effort to pass legislation. Members of the Council of Ministers-regardless of their status as members of the ruling family, elected deputies, or others - -tend to vote as a distinct bloc. This feature of the Kuwait National Assembly provides analysts and observers of Kuwaiti politics with tremendous insight into how the Council of Ministers (and by extension, the Emir) feel about a particular piece of legislation.

\section{Data and Approach}

To test our hypotheses about strategies of cooptation and their effectiveness, we develop a dataset of historical roll call voting in the KNA. The Kuwait National Assembly Roll Call Votes dataset includes individual roll call votes for successful legislation passed by the KNA from 1963 to 2016. To collect these data, we first downloaded digitized .pdf files of legislative transcripts from the Kuwait National Assembly Archive ${ }^{13}$ A total of 3,595 laws were passed by the KNA from 1963 to 2016. With significant support from a team of research assistants, we then identified the roll call

\footnotetext{
${ }^{12}$ A majority of deputies can vote to waive this requirement after the first deliberation is approved.

${ }^{13}$ These legislative transcripts are colloquially referred to as "minutes" (madbata, pl. madābit) in Kuwait. The full archive consists of 551,605 pages across 2,294 .pdf files (2,188 unique meeting days).
} 
voting record for a given law in the transcripts and hand coded vote choice for all participants. We successfully identified records for 3,337 laws (0.928 percent). We describe the data collection process in greater detail in Section S.1 in the Supplementary Materials appendix.

We limit our focus to successful legislation for both practical and substantive reasons. First, Kuwaiti record-keeping makes it logistically impossible to track a single piece of legislation through all stages of the deliberation process: bills are not assigned unique identifiers, and, for laws that pass, only the date of the final vote is documented. Additionally, there are substantive reasons to focus on a single type of vote ("second deliberations") rather than including all procedural and amendment votes, for which deputy decision-making may be driven by a wider range of concerns (such as the timing of a vote or an objection to ending deliberation). Within this category, we might seek to broaden our focus to examine all second deliberations, including on legislation that failed to pass 14 but even such an approach includes a strong selection effect. It is relatively rare for a final vote to fail; as in other legislative institutions, the decision to initiate a final vote is discretionary, and in most cases, the government will avoid the public embarrassment associated with a failed vote by never bringing such a bill to the floor.

Does the scoping condition of final votes on ultimately successful legislation impede our ability to test the hypotheses spelled out in section 2.1? In this paper, we seek to examine and test the mechanisms of cooptation rather than the regime's overall ability to pass the legislation that it wants. Our focus is thus on cooptative action taken by the regime and MP behavior in response. We would expect patterns in cooptation to generalize throughout the legislative process: if the regime is in fact offering rents in exchange for cooperation, it likely does so in preceding deliberations as well. And the focus on final votes allows us to examine opposition and cooperation at a point when decisions are most substantively and directly impactful.

Because Kuwaiti procedure allows the legislature to bundle multiple laws into a single final vote, our full dataset includes 2,693 "second deliberation" votes. We do not disaggregate these unique laws: when a second deliberation vote is held on multiple laws, they are included as a single event in the dataset. Figure 2 displays the distribution of these 3,337 laws and 2,693 second deliberation votes from 1963 to 2016. Notably, voting concurrently on multiple laws has become more prevalent

\footnotetext{
${ }^{14}$ This would also entail insurmountable logistical hurdles given the lack of documentation and identifiers as well as variations in procedure across terms.
} 
in recent terms, though the majority of laws (78\%) are voted on individually. Laws that are bundled into a single vote are typically substantively linked or cover related topics. For example, one second deliberation vote in 2013 covered 14 different international agreements, including bilateral treaties, Arab League charters, and other international conventions. The total number of laws passed per term has also increased over time: the earliest assemblies passed fewer than 200 laws, while the 2013 assembly passed nearly $4 0 0 \longdiv { 1 5 }$

Figure 2: Legislative activity in the Kuwait National Assembly, 1963-2016

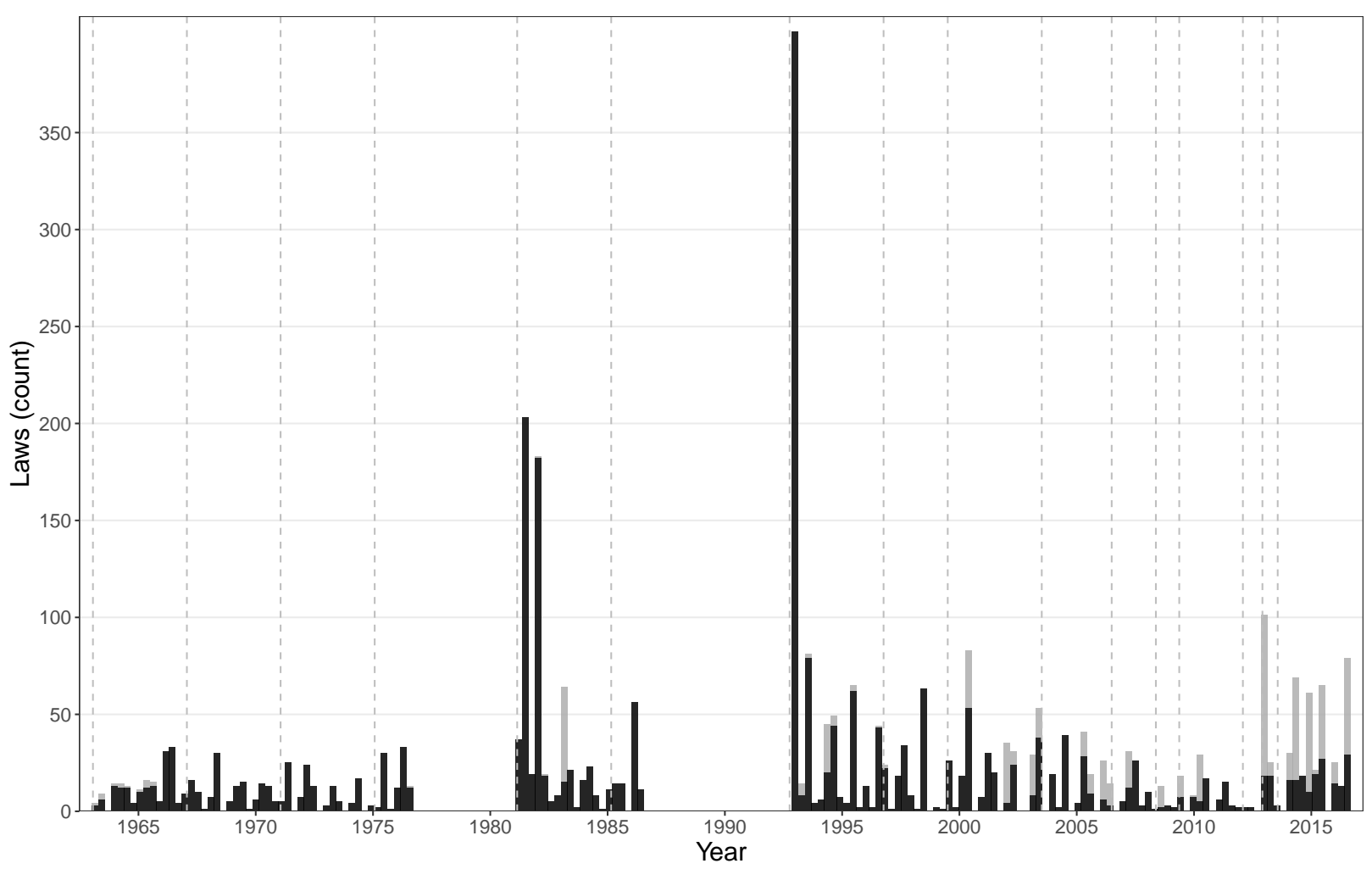

Note: Laws passed $(N=3,337)$ and unique "second deliberation" votes $(N=2,693)$ in the Kuwait National Assembly (KNA). Gray lines count unique laws; black lines count unique "second deliberation" votes. Dashed vertical lines signify elections and the start of a new term. In the post-liberation period, the KNA began voting on multiple laws concurrently with greater frequency. Source: Kuwait National Assembly Roll Call Votes (KNA-RCV) dataset.

Table 2 displays basic descriptive statistics in voting patterns, summarizing the number of yes, no, and abstain votes by deputies and ministers. In total, the dataset includes 168,474 observations. At first glance, a few patterns are clear. First, absences are relatively common, and ministers are

\footnotetext{
${ }^{15}$ The spikes in activity at the beginning of the 1981 and 1992 terms can be attributed primarily to a large backlog of legislation initiated by the emir during the preceding years when no assembly was in place and, in the case of the 1992 term, to an additional rush of post-conflict legislation following the Iraqi invasion.
} 
absent more often than their deputy peers (45\% of the time compared to $31 \%$ ). We interpret deputy absences as evidence of shirking duty rather than as a form of protest; we find that low attendance rates are negatively correlated with other confrontational actions such as minister queries Malesky \& Schuler 2010 and interpellations. Minister attendance, in contrast, is likely at least in part a strategic action related to the competitiveness of a given vote. A closer vote margin among deputies is associated with a higher number of ministers present, suggesting the regime deploys ministers when it needs the additional votes to ensure legislation is successful.

Second, in contrast to more democratic contexts, the legislature demonstrates a great deal of consensus: the vast majority of votes submitted are in favor of legislation 16 Noes and abstentions constitute only $7 \%$ of total votes cast. And yet, as we will show, there is substantial variation in these quantities at both the term and deputy level. Notably, deputies are significantly more likely than ministers to register a vote of no or abstain. In the next section, we examine voting patterns among ministers more closely and define our primary outcome variable.

Table 2: Kuwait National Assembly Roll Call Votes dataset, 1963-2016

\begin{tabular}{ccc}
\hline \hline & $\boldsymbol{N}$ & Mean \\
\hline Deputy votes & 84,053 & \\
Yes & 4,082 & 0.63 \\
No & 4,452 & 0.03 \\
Abstain & 41,781 & 0.03 \\
Absent & 134,368 & 0.31 \\
\hline Total Deputy votes & & 1.00 \\
\hline Minister votes & 22,761 & \\
Yes & 204 & 0.54 \\
No & 226 & 0.00 \\
Abstain & 18,740 & 0.01 \\
Absent & 41,931 & 0.45 \\
\hline Total Minister votes & 1.00 \\
\hline
\end{tabular}

Note: Table displays the number of yes, no, abstain, and absent votes among deputies and ministers. The total number of roll call votes in the dataset is 168,474 . This number does not equal the sum of deputy and minister roll call votes separately, as elected deputies can serve as ministers as well. Source: Kuwait National Assembly Roll Call Votes (KNA-RCV) dataset.

\footnotetext{
${ }^{16}$ There is, of course, a selection effect here in that we are examining only successful legislation, so we derive stronger inference from the comparison between deputy and minister behavior.
} 


\subsection{Dependent Variable: Voting with Ministers}

To test $\mathrm{H}_{1}$ and $\mathrm{H}_{2}$, we seek to identify whether a deputy votes with or against the regime on each piece of legislation under review. In general, one might identify the regime's position on a given policy in a number of different ways: by examining the origin of the legislation, through media reporting, or through the votes of elected representatives allied with the regime. In the Kuwaiti case, we take advantage of the distinctive institutional feature outlined above: the ability of ministers appointed by the regime to vote alongside elected MPs on legislation. This unique characteristic of the Kuwaiti constitution effectively grants the regime a way to keep a sometimes truculent legislature in check: ministerial appointments are at the Emir's sole discretion. He may remove or replace a minister for any reason and does so with relative frequency; the average term saw five cabinet changes, typically involving the replacement of a single minister ${ }^{17}$

As a result, we expect ministerial votes to reflect the regime's policy preferences, as he could immediately remove and replace a minister that refused to support his preferred policies within the legislature. Consistent with this expectation, analysts have noted that Kuwaiti ministers generally vote as a bloc (i.e. without opposing votes between ministers) on important or high-profile pieces of legislation. We use the KNA-RCV dataset to examine this anticipated voting cohesion across the entire history of successful legislation and find that it is very much the rule: across the 2,693 unique roll call votes in our dataset, there were only five instances in which active ministers submitted both yes and no votes on a single law. All of these instances took place in 1963 - the very first year of KNA history. Since then, there has not been a single instance of vote-splitting among cabinet members on second deliberations.

This near-perfect voting cohesion corroborates our expectation that ministers are bound in practice to uphold the position of the regime on a given piece of legislation - or at least not openly oppose it 18 We therefore use minister votes to benchmark regime opinion on a policy,

\footnotetext{
${ }^{17}$ Ministers can also be removed through legislative consensus (an interpellation followed by a vote of no confidence). This is relatively unusual - though, as mentioned above, the threat of a successful interpellation and minister removal can compel the regime to take preventative action. And, importantly, though the legislature can in theory force the removal of an unpopular minister, they cannot separately impact the selection of his replacement. In practice, such confrontations sometimes lead instead to the dissolution of the legislature and new elections.

${ }^{18}$ In many cases, ministers are absent during the final vote (see Table 2), and, when present, they occasionally opt to abstain from voting on a particular law. In a small set of cases (30 votes), all ministers present opted to abstain during the final vote. Additionally, there are a handful of cases (eight total votes) in which some of the ministers present cast a valid vote on legislation while others chose to abstain. In all other laws in our dataset, the ministers present were unanimous in support or opposition to the legislation being voted on.
} 
assuming that the regime supports the passage of a piece of legislation if at least one minister votes in favor and none vote against, and opposes it if at least one minister votes against and none vote in favor. ${ }^{19}$ The outcome described in hypotheses 1 and 2 - cooperation with the regime-is therefore operationalized as Cooperation, (voting with the cabinet) defined as 1 if a deputy votes yes on a policy ministers support or no on a policy they oppose, and 0 otherwise.

\subsection{Independent Variable: Oil Rents}

In $\mathrm{H}_{1}$, we predict that more rents available to the regime will be associated with increased cooperation with the regime's policy agenda. We seek to test this on a within case basis, using oil prices and revenues as a proxy for regime funds. Though an ideal measure would directly capture financial transfers and perks transmitted directly to active MPs, such financial data are not available in this context. ${ }^{20}$ Yet there is reason to expect that they occur regularly outside of public view. A majority of Kuwaitis (64\%) believe that there is corruption within state agencies and institutions ${ }^{21}$ In 2011, the revelation that millions of dollars had been transferred into the bank accounts of two acting MPs (and the subsequent investigation into the finances of an additional seven MPs) led to broad public outrage and contributed to the dissolution of the 2009 assembly ${ }^{22}$ So, while it is not possible to identify and track these illicit bank transfers, business dealings, and other off-the-books "perks" distributed to office holders, there is ample reason to believe they occur in this context.

And Kuwaiti oil rents plausibly serve as a measure of the revenues available to the regime. Kuwait has the fourth largest oil reserves in the world and derives the majority of its wealth from this resource. There is a long history of oil revenues funding the ruling family, beginning with the remittances received from the newly formed Kuwait Oil Company in 1935 Crystal 1992, p. 18) and continuing more directly when that company was nationalized in 1976, with the effect that oil revenues now "go directly to the state" Crystal 1992, p. 102). Despite government efforts to diversify its income, it remains heavily dependent on oil: between 1993 and 2015, oil rents

\footnotetext{
${ }^{19}$ For this analysis, we drop the five cases with mixed voting and the 30 cases in which all ministers present opted to abstain ( $1 \%$ of final votes in our dataset).

${ }^{20}$ Though this type of corruption is believed to exist across a wide range of regimes, it is rare to find direct measures of its presence. See McMillan \& Zoido 2004 and Szakony 2018 for direct and indirect evidence of such transfers in the Peruvian and Russian contexts, respectively.

${ }^{21}$ Estimated using survey data from the Arab Barometer collected in 2014.

${ }^{22}$ The MPs in question were never publicly named. For an English-language accounting of the scandal, see Stack, Liam. (2011, September 21). "Corruption inquiry rocks Kuwait." New York Times.
} 
comprised, on average, a whopping $91 \%$ of total government revenues ${ }^{23}$

Figure 3: Oil prices and Kuwaiti oil rents over time
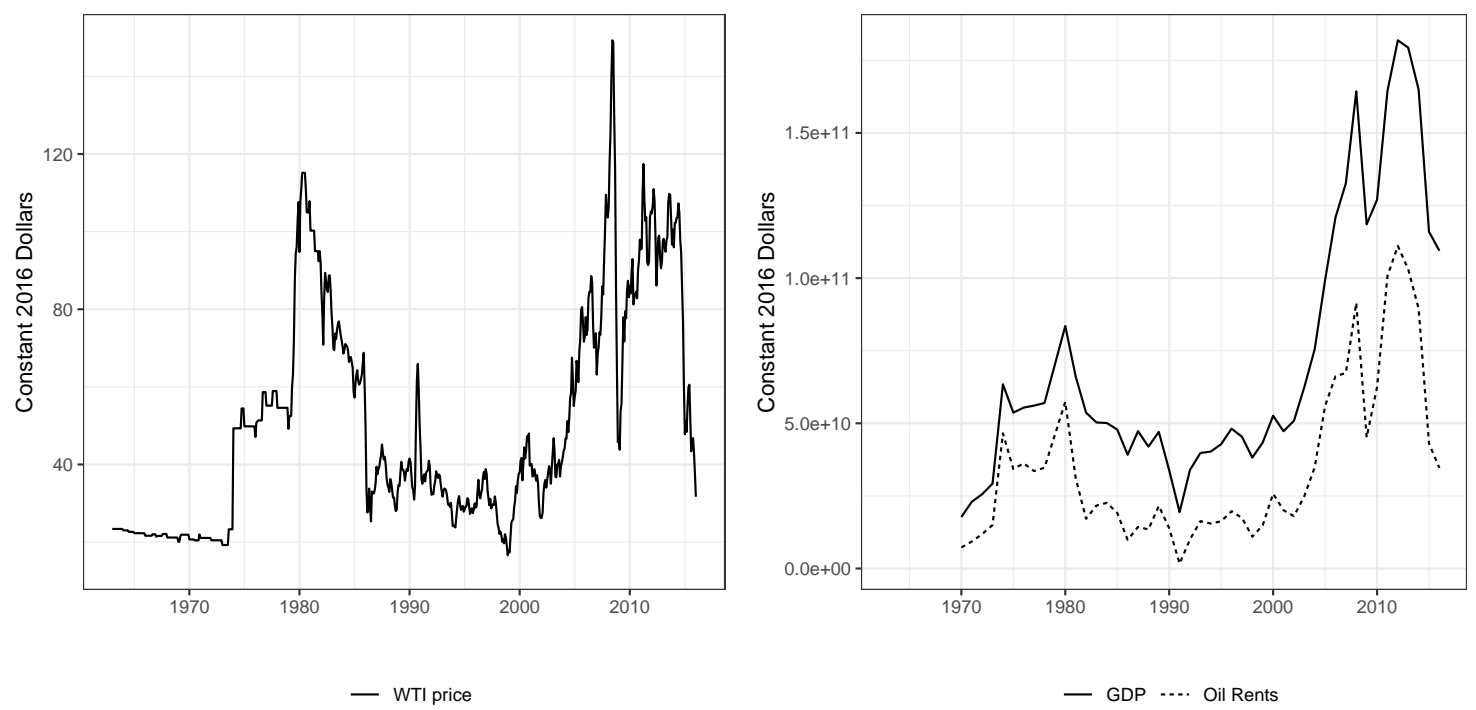

Note: Left panel plots changing oil prices from 1963-2016, estimated using monthly spot crude oil prices for West Texas Intermediate and shown in constant 2016 USD. Right panel plots annual Kuwait GDP (solid line) and oil rents (dotted line) from 1970-2016, estimated using data from the World Bank and shown in constant 2016 USD.

Oil has made Kuwait a wealthy nation. But wealth based on a single rentier commodity is not without its challenges Ross 2012). Oil is one of the most volatile commodities in existence (see Figure 3, left panel). ${ }^{24}$ Kuwait has some influence over oil prices due to its high total output (roughly $6 \%$ of global production) and membership in the Organization of the Petroleum Exporting Countries (OPEC), which has sought to control prices through production scaling over the past half century with mixed results. But to a large degree, government revenues are dependent on and thus vulnerable to global demand for this critical commodity. As a result, Kuwaiti government revenues - tied directly to prices following the nationalization of the oil industry - go through abrupt, largely exogenous boom and bust periods. ${ }^{25}$ Between 2014 and 2015, for example, Kuwaiti oil revenues fell by nearly half from 26.5 billion to 13.6 billion dinars - and, correspondingly, gov-

\footnotetext{
${ }^{23}$ Central Bank of Kuwait. The bank does not report government revenues for earlier periods, but this is consistent with analyses of preceding time periods Eltony \& Al-Awadi 2001).

${ }^{24}$ Using historical price data, Regnier 2007) found that oil and natural gas prices were more volatile than those of $95 \%$ of other products sold in the US.

${ }^{25}$ The one clear instance of domestic events affecting international oil prices was the spike in 1990 following the Iraqi invasion of Kuwait (Figure 3. Yet, notably, this was during a period of legislative dissolution and is therefore outside the scope of our dataset (Figure 2 .
} 
ernment revenues dropped from 29 billion to 15.1 billion dinars.26

In theory, the government could mitigate the high risk of its oil-based portfolio by carefully managing expenditures and banking the surplus for future periods of revenue uncertainty. In practice, there is evidence that Kuwait has not been entirely successful in this approach. Like other Gulf states, Kuwait has constructed a welfare state in which the government is responsible for a vast amount of social programming directed at citizens (El-Katiri et al. 2013). This spending closely tracks income: Eltony \& Al-Awadi 2001 and Burney et al. 2018 find evidence that government expenditures are a function of oil revenues. From 1993-2015, annual government expenditures averaged $84 \%$ of oil revenues in a given year. Finally, some aspects of government spendingparticularly the vast array of consumer subsidies - have produced a sustained strain on accounts. In 2014, the IMF reported that Kuwait could run a budget deficit as early as 2017 under the weight of its subsidies; this actually occurred two years ahead of schedule following the 2015 drop in oil prices 27

We therefore use oil as our primary measure of available rents - essentially as a proxy for the marginal value of cash to the regime. We measure this in two ways: first, through monthly crude oil prices in constant dollars (WTI Price) ${ }^{28}$ and second, by calculating oil revenues on a monthly basis using the price of oil and Kuwait's estimated daily production (Oil Revenues) ${ }^{29}$ The former metric has the advantage of a wider data range, covering the entirety of KNA history, and a greater claim to exogeneity, as the Kuwaiti government has a more limited ability to influence global prices. The latter is somewhat endogenous to government decision-making (the regime might, for example, increase production to help offset losses from falling oil prices or when it faces more parliamentary opposition) but more directly captures the rents available to the regime in a given period. We lag each measure by one month to account for time delays between oil sales and regime access to (and ability to disburse) the resulting funds. We standardize these continuous variables in the regression models that follow for ease of interpretation of the resulting coefficients.

\footnotetext{
${ }^{26}$ Central Bank of Kuwait.

${ }^{27}$ Oil prices have only fallen further since then, but the Central Bank of Kuwait has not published information on government expenditures since 2015 .

${ }^{28}$ We use spot crude oil prices for West Texas Intermediate (WTI) as our primary measure of oil price due to its long history in the global market.

${ }^{29}$ We access historical data dating back to 1973 on Kuwaiti oil production via YCharts, a widely used investment research platform.
} 


\subsection{Independent Variable: Cabinet Positions}

We next operationalize policy concessions granted to active MPs. Again, this poses measurement challenges: identifying specific modifications to proposed laws and the individuals that would benefit from them is extremely challenging in this context. Even if we could track the individual concessions included in each law, we have no way of establishing a basis for comparison to the regime's ideal policy 30 We instead use an observable implication of policy concessions: ministerial positions provided to individuals affiliated with various factions, or "proto-parties" in the Kuwait context Kraetzschmar 2018. Consistent with $\mathrm{H}_{2}$, we predict that when the regime provides these groups with representation on the Council of Ministers, elected deputies belonging to these groups will be less likely to vote against the Council of Ministers. In this sense, we use observable variation in policy influence as a proxy for policy concessions.

The provision of policy influence serves as a plausible measure of policy concessions for several reasons. First, as discussed above, ministers serve as ex officio, voting members of the legislature. When a group is given a particular ministerial portfolio, those groups are expected-but not obligated - to support the government's agenda and coordinate accordingly. Second, representation on the Council of Ministers confers recognition and legitimacy to some groups at the expense of others. If a particular group refuses to participate in a particular cabinet, another group with different priorities, preferences, and policy goals could be offered the position. Because the government requires some modicum of legislative support, it appeals to these groups in order to advance its own, broader political agenda. Finally, and most significantly, as in most parliamentary systems, a majority of laws originate within and are initiated by the Council of Ministers. As a result, ministers are not just responsible for the effective functioning of their ministries: they actively design and shape proposed legislation designed to regulate particular ministerial activities, meaning they have an opportunity to influence policy before it hits the legislative floor. For elected deputies that comprise these groups, having a compatriot in the cabinet means draft bills initiated by the government are more likely to represent their political and ideological interests. Among the votes submitted by MPs in our dataset, $21 \%$ were registered while the voter had an ideological

\footnotetext{
${ }^{30}$ This is a problem that other scholars have dealt with in other contexts. Reuter \& Robertson 2015 use committee leadership positions as a measure of cooptative concessions in Russian subnational legislatures. In Kuwait, the regime does not have a direct role in committee appointments: membership is voted on in the entire legislature and leadership appointments are determined by vote within committees (meaning ministers cannot participate).
} 
representative on the cabinet.

In the Kuwait context, elected deputies and ministers may belong to one of six groups, or "proto-parties:" national-liberal, Muslim Brotherhood, Salafi, independent Islamist, Shia Islamist and leftist-populist. In the 1960s and 1970s, national-liberal and Muslim Brotherhood affiliates were given key ministerial portfolios on the Council of Ministers. The ruling family discontinued this practice in 1981 and throughout the 1980s, following the restoration of the National Assembly. But when the National Assembly was again restored following the Iraqi invasion and occupation of Kuwait, this practice continued. After the 1992 election, for example, six elected deputies representing these movements were given ministerial portfolios on the Council of Ministers. According to Ghabra 1993 pp. 19), "The raison d'etre of the opposition members of the government was the initiation of reform programs in and through their ministries, to put into practice the ideals and slogans of the campaign." Figure 4 depicts cabinet composition over time with respect to the six proto-parties as well as the participation of the Al-Sabah family.

In practice, these groups have occasionally used their control over ministerial portfolios to design and implement these limited reforms. But more publicly, these groups have also used their influence on the Council of Ministers to pass policy-focused legislation important to their constituents. For example, in 1996, Islamist political groups in the legislature worked with the Council of Ministers to pass a law ending coeducation at Kuwait University. Though the government had repeatedly opposed efforts to enforce gender segregation, it eventually caved. Similarly, in 2008, the government appointed a member of the National Islamic Coalition, a Shia Islamist group, as Minister of Public Works and Minister of State for Municipal Affairs. Analysts and observers speculated that the appointment would allow the new minister to expand permits and licenses for hussainiyat, or congregation halls for Shia religious ceremonies. In exchange, the group's deputies were expected to support the government in the legislature. We discuss these groups in greater detail and provide additional examples of these policy concessions in Section S.3 in the Supplementary Materials appendix.

As discussed above, the Emir has full discretion over ministry appointments. Many of these ministers (around 30\%) are selected from within the Al-Sabah family, which does not participate 
Figure 4: Cabinet composition over time

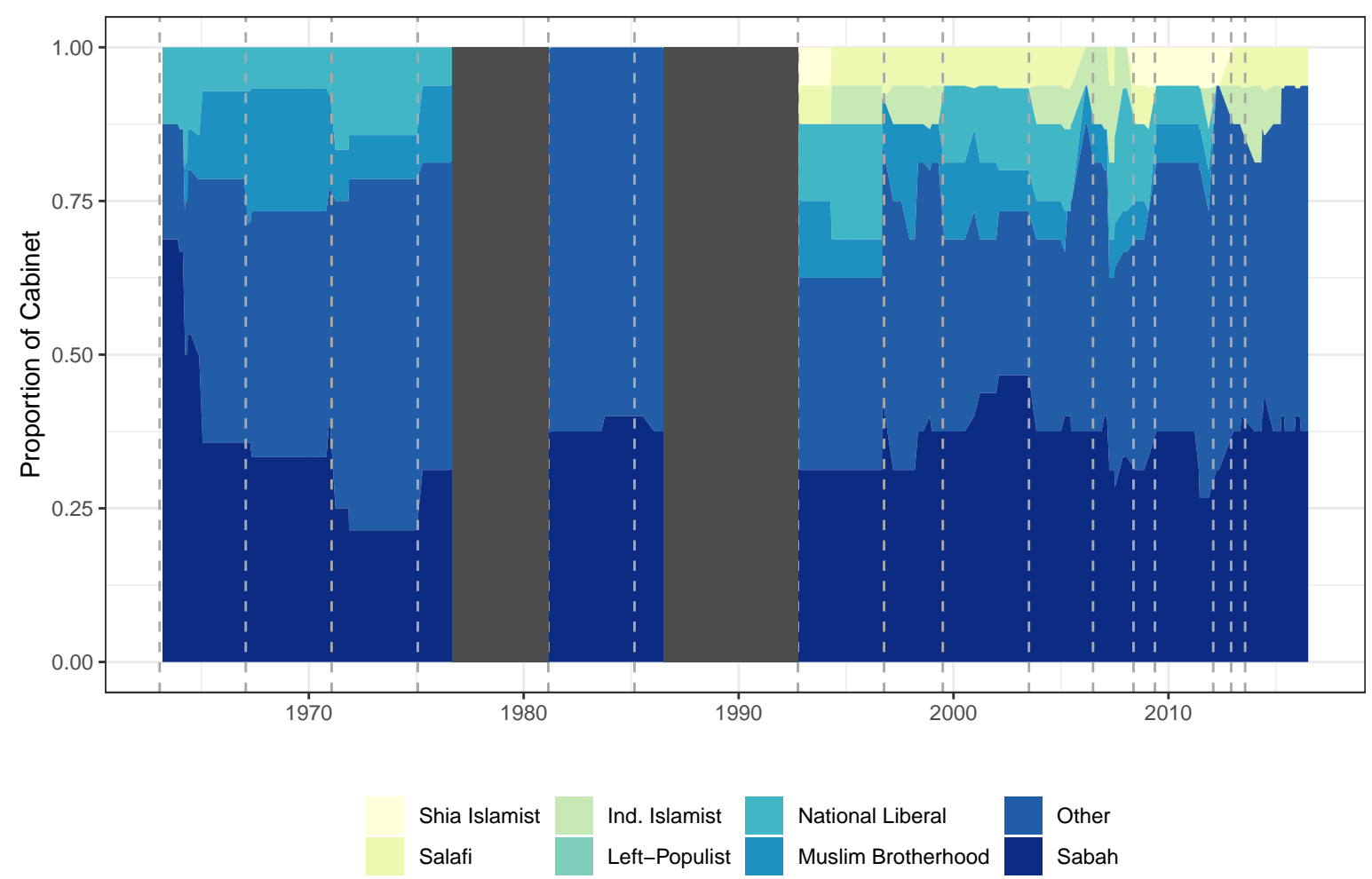

Note: Figure depicts the historical proportion of cabinet members representing different groups, including the ruling Al-Sabah family as well as six ideological proto-parties. Dotted lines indicate the start of a new term (when a cabinet is formed), and dark gray space represents time when the legislature was dissolved for an extended period.

in elections ${ }^{31}$ Yet other ministers are appointed from existing factions and groups within Kuwaiti society and politics: these groups are also represented among elected deputies in the legislature, as well. To capture these affiliations, we code Cabinet Affiliate, a variable coded as 1 for votes where the deputy in question had an ideological affiliation with an acting minister and 0 otherwise ${ }^{32}$ We also code a dummy variable for whether or not a deputy has any ideological affiliation (that is, whether or not he or she is eligible for this treatment).

\footnotetext{
${ }^{31}$ This tradition of broader family involvement in political life predates the current constitution, when the acting Emir tapped his relatives to serve as political advisers or department heads, and has continued throughout the decades of KNA history Crystal 1992 pp. 92-93). The most important posts (such as the ministries of the interior or defense) are almost exclusively reserved for family members Herb 2002.

${ }^{32}$ For example, for a member of the Shia Islamist bloc, this variable would be coded 1 for all votes when at least one concurrent cabinet member was also a participant in the Shia Islamist bloc.
} 


\subsection{Approach}

We first seek to understand the extent to which observable measures of cooptation (oil rents and ministerial appointments) are linked to actual voting behavior on policies close to being enacted $\left(\mathrm{H}_{1}\right.$ and $\left.\mathrm{H}_{2}\right)$. We therefore model cooperation with ministers as a function of our two independent variables.

There are, of course, a number of potential confounders in establishing a linkage between rents and policy concessions and voting behavior. Specifically, we expect that the regime's use of these two mechanisms is the result of a strategic interaction between MPs and the regime. For example, we might expect the regime to make greater use of its cooptative mechanisms in terms when more MPs are elected who are predisposed to oppose the regime - which would depress the observed effect on voting with cabinet members. Additionally, we expect the regime to respond to the specific legislators elected and their interest in different types of concessions. From an empirical standpoint, then, we control for both assembly and deputy characteristics in our observational regressions. We include term fixed effects in all models to account for specific circumstances associated with each term. We also estimate models with controls for MP characteristics (including demographics such as age, gender, and education as well as occupational categories, sect, and tribal affiliation) or with legislator fixed effects.

We also expect law content to matter for deputy support. We undertake prelimiinary coding to identify the subject matter of each law in our dataset. We expect that some areas of legislation, such as international treaty agreements, are unlikely in general to elicit much opposition within the legislature, while others, such as laws dealing with electoral rules, will prove more controversial. ${ }^{33}$ We therefore include dummy variables for four topics in each model of deputy voting: budgets and other fiscal legislation, treaties, oil, and elections.

Finally, to test the prediction that rents are more effective at buying off non-ideological politicians $\left(\mathrm{H}_{3}\right)$, we look for separate effects of oil prices and revenues on deputies with and without an ideological affiliation. We drop deputy FEs in this analysis, since this is typically a fixed attribute for politicians.

\footnotetext{
${ }^{33}$ We find that this is in fact the case, though there is considerable variation in support within topics (see Appendix Figure A.3.
} 


\section{Results}

We begin by presenting descriptive information about our data and primary dependent variable before turning to more direct tests of our hypotheses.

First, we look at general patterns in deputy cooperation in the KNA. Though deputies vote with the regime in the vast majority of cases (92\% of votes from present deputies aligned with the minister bloc), this belies considerable variation on a per law and per deputy basis. Figure 5 plots our primary outcome variable over time, grouped into quarterly intervals. It is especially interesting to note that cooperation with the regime was often at its lowest level toward the end of a term; in some cases, a decline in cooperation directly preceded an early dissolution of the assembly by the Emir - evidence that in some cases, the regime fails to effectively coopt the legislature.

Figure 5: Cooperation in the Kuwait National Assembly, 1963-2016

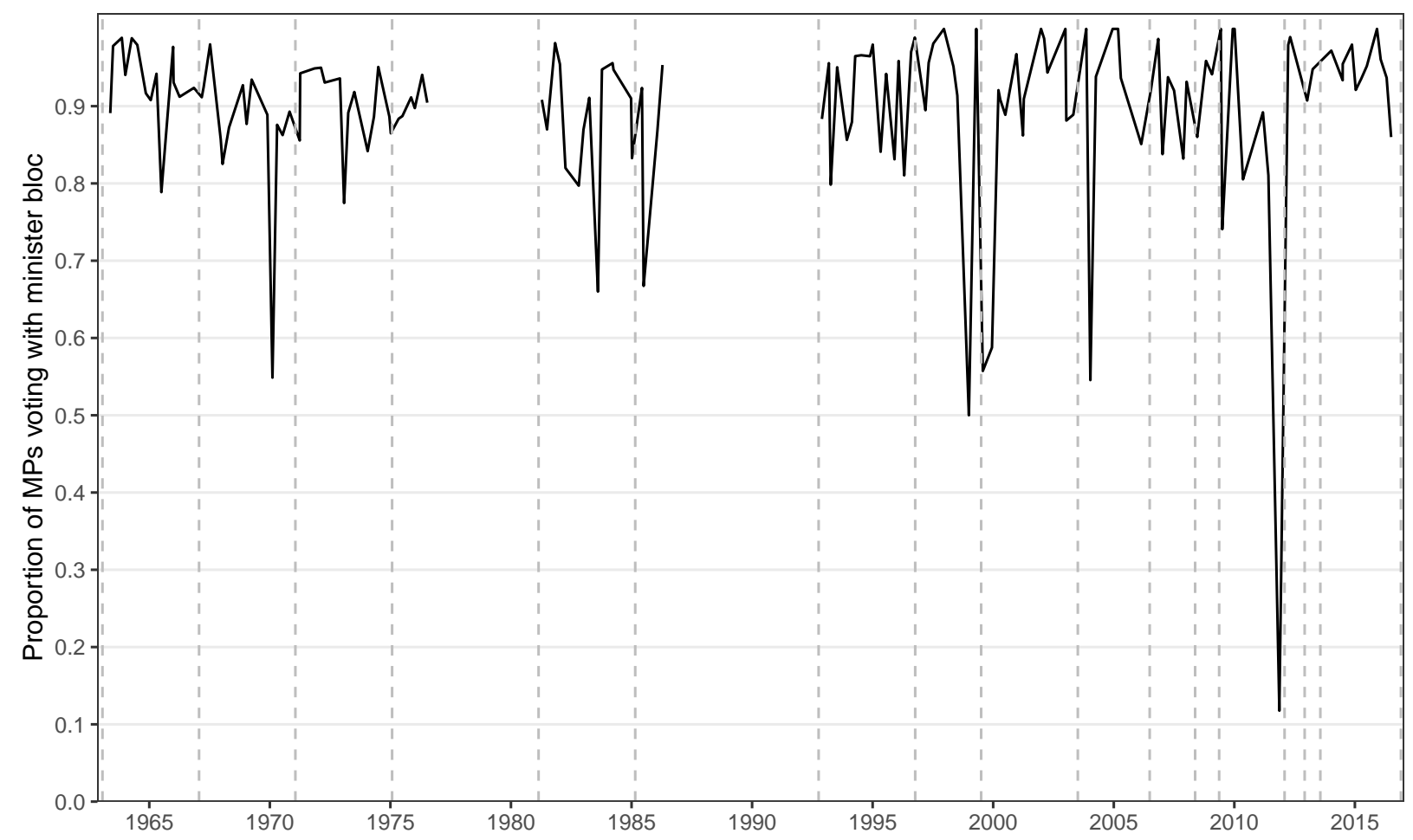

Note: Plot displays the average rate of elected deputies with the cabinet bloc in the Kuwait National Assembly in quarterly intervals. Line indicates the average proportion of roll call votes in support of the minister consensus across laws passed in the interval. Dashed vertical lines signify elections. The legislature was suspended during two periods (1976-1981 and 1986-1992). Source: Kuwait National Assembly Roll Call Votes (KNA-RCV) dataset.

In Figure 6, we plot the distribution of regime support at the second deliberation level (left 
panel) and the deputy-term level (right panel). Most laws voted in the KNA pass by a wide margin: $30 \%$ were enacted unanimously, and three-quarters achieved $90 \%$ cooperation from elected MPs. Yet there is evidence of substantial opposition in the remaining $25 \%$ of votes. Over the history of the KNA, a handful of laws were passed despite minister opposition - in other words, the presumed regime preference was explicitly overruled in exactly 28 cases (1\% of our dataset). ${ }^{34}$ In a number of other cases, a sizable bloc of deputies voted against the regime - in other words, some laws were only successful because of the regime's built-in advantage 35

Figure 6: Voting with ministers.
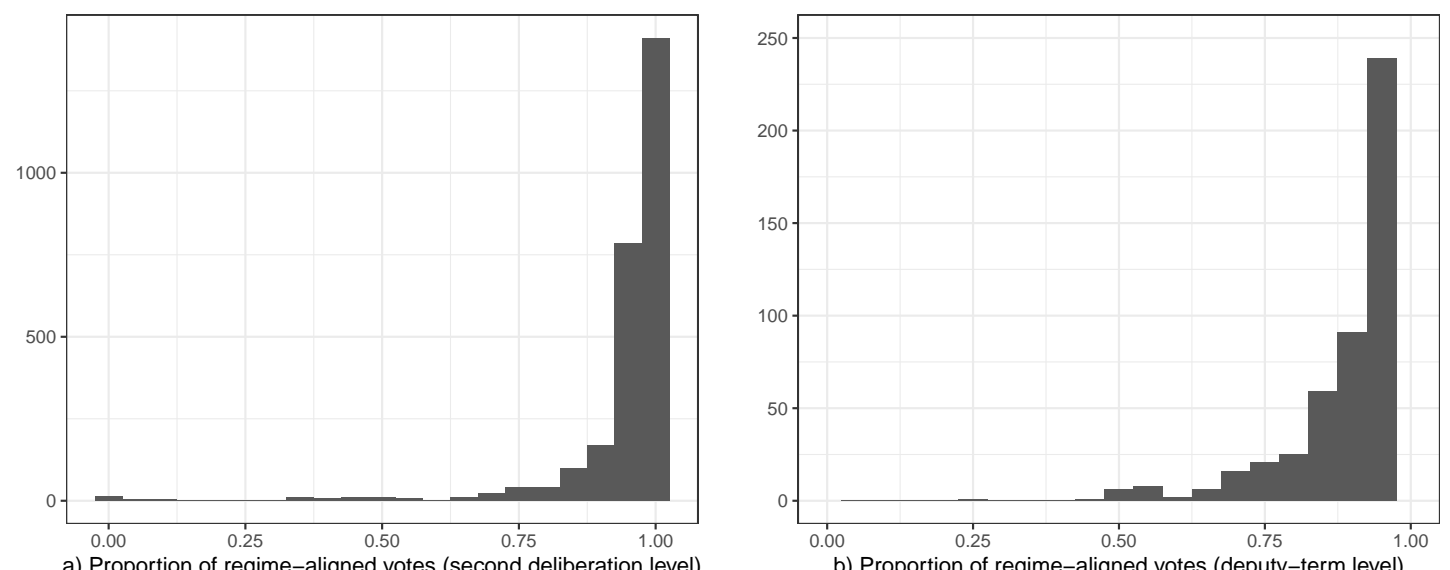

Note: Figure plots the distribution of cooperation (voting with the minister bloc) at the law level (left panel, $\mathrm{n}=$ 2658) and deputy-term level (right panel, $\mathrm{n}=800$ ).

The distribution of deputy behavior also reveals considerable variation. While $14 \%$ of deputies voted with ministers on every single final vote, another $11 \%$ only cooperated $75 \%$ of the time. The median deputy supported the regime on $93 \%$ of votes - evidence of considerable allegiance, but not total sycophancy. It is important to keep in mind that voting against the regime on a final deliberation has significant policy relevance and can therefore be distinguished from other, more performative legislative actions. We thus interpret these votes as costly actions for deputies to take.

\footnotetext{
${ }^{34}$ These cases are distributed widely across terms and most legislatures had at least one law pass despite minister opposition. The topics of these laws vary widely but include issues related to the civil service or individual compensation (seven laws), one issue of election law, and one issue related to criminal proceedings against ministers.

${ }^{35}$ This is most obvious in the 36 deliberations in which a majority of MPs voted against: these passed only because the cabinet was able to overcome the vote margin. Note that there are likely additional deliberations where minister support was insufficient to overcome MP opposition; because we collect data on successful legislation, we do not explicitly examine the frequency of such events.
} 


\subsection{Rents, Policy Concessions, and Cooperation}

We next turn to our proxies for regime concessions and examine whether they predict deputy voting behavior. Table A.2 reports outputs from OLS models at the deputy-vote level of voting with the regime $\sqrt{36}$ We first examine whether oil prices (models 1 and 2) and revenues (models 3 and 4) are linked to cooperation. We find that both are positively associated with voting with the regime in comparable ways: a standard deviation increase in either variable is associated with an expected 1.5 percentage point increase in voting with the regime. These effects are significant at the $\alpha=0.001$ level and effect sizes are largely unchanged with the inclusion of deputy FEs.

In models 5 and 6 , we examine whether ministerial appointments predict voting behavior. Here, as predicted, we find that deputies with an ideological affiliation increase their level of cooperation when there are one or more active ministers with the same affiliation. Interestingly, such deputies are in general less likely to support regime policy, consistent with the idea that participation in a political bloc is a signal that an individual opposes the status quo policy advanced by the regime. The coefficient on cabinet affiliation is more sensitive to the inclusion of deputy FEs, which substantially reduce the total variation in the sample ${ }^{37}$ but remain significant in both specifications. In the specification with MP controls, we find that the addition of an affiliated cabinet member is associated with an expected 1.4 percentage point increase in voting cooperation-substantively, very similar to the effect of oil rents.

We next turn to empirical tests of hypothesis 3 . We consider whether the positive impact of oil prices on cooperation with the regime is specific to deputy type. In particular, we predict that because ideologically-oriented deputies prefer policy concessions to rents, they will not be as responsive to increased rents. In Table 4, we interact oil metrics with a measure of deputy ideology. The interaction coefficient is negative in both specifications, though it is substantively larger and significant in the specification including Kuwaiti oil revenues. We interpret this as evidence that policy-oriented deputies (defined as those with an affiliation to an ideological bloc) are less moved by oil rents than other deputies.

\footnotetext{
${ }^{36}$ In section $\mathrm{S} .4$ we report output from equivalent probit specifications; results are largely consistent with the OLS output.

${ }^{37}$ This is the result of two features: first, ideological affiliation is typically a constant attribute for deputies, and second, cabinet changes in the middle of the term occur sporadically. As a result, the inclusion of both term and deputy fixed effects absorbs a majority of the variation in the cabinet affiliation variable.
} 


\begin{tabular}{|c|c|c|c|c|c|c|}
\hline & \multicolumn{6}{|c|}{ Dependent variable: } \\
\hline & \multicolumn{6}{|c|}{ Voting with regime } \\
\hline & $(1)$ & $(2)$ & $(3)$ & $(4)$ & $(5)$ & $(6)$ \\
\hline WTI Price & $\begin{array}{c}0.015^{* * *} \\
(0.002)\end{array}$ & $\begin{array}{c}0.016^{* * *} \\
(0.002)\end{array}$ & & & & \\
\hline Cabinet Affiliate & & & & & $\begin{array}{c}0.014^{* * *} \\
(0.002)\end{array}$ & $\begin{array}{c}0.006^{* *} \\
(0.002)\end{array}$ \\
\hline Ideology Dummy & & & & & $\begin{array}{c}-0.040^{* * *} \\
(0.003)\end{array}$ & $\begin{array}{c}-0.038^{* * *} \\
(0.007)\end{array}$ \\
\hline Oil Revenues & & & $\begin{array}{c}0.015^{* * *} \\
(0.002)\end{array}$ & $\begin{array}{c}0.017^{* * *} \\
(0.002)\end{array}$ & & \\
\hline Term FEs & $\checkmark$ & $\checkmark$ & $\checkmark$ & $\checkmark$ & $\checkmark$ & $\checkmark$ \\
\hline MP FEs & & $\checkmark$ & & $\checkmark$ & & $\checkmark$ \\
\hline MP controls & $\checkmark$ & & $\checkmark$ & & $\checkmark$ & \\
\hline Topic controls & $\checkmark$ & $\checkmark$ & $\checkmark$ & $\checkmark$ & $\checkmark$ & $\checkmark$ \\
\hline Observations & 82,209 & 82,209 & 70,294 & 70,294 & 82,209 & 82,209 \\
\hline $\mathrm{R}^{2}$ & 0.032 & 0.097 & 0.037 & 0.112 & 0.034 & 0.096 \\
\hline
\end{tabular}

Table 3: Cooptation strategy and voting with the regime. Table reports coefficients from OLS models of voting consistent with the minister bloc at the deputy-vote level. All models include term fixed effects and indicators for law topic (budget/fiscal, treaty, oil-related, or electoral). Models alternately include controls for legislator attributes (age, gender, education, sect, occupation, and tribal affiliation) or legislator fixed effects. WTI price and oil revenues are standardized continuous variables.

\subsection{Regime Strategic Considerations}

Thus far we have presented evidence that both of the mechanisms proposed by cooptation theory are effective in inducing legislative support for the regime's policy agenda. While this offers some confirmation of our theoretical expectations, it leads to additional questions about the strategic interaction between the regime and elected legislature. One follow-on question of particular interest is under what conditions will the regime deploy these two mechanisms - that is, what determines the specific strategy selection of how many rents and policy concessions to employ?

We expect that the regime's use of cooptation will vary in response to a range of environmental and policy-oriented factors. For example, the regime might increase its use of cooptation when it 


\begin{tabular}{|c|c|c|}
\hline & \multicolumn{2}{|c|}{ Dependent variable: } \\
\hline & \multicolumn{2}{|c|}{ Cabinet Ideological Bloc } \\
\hline & $(1)$ & $(2)$ \\
\hline WTI Price & $\begin{array}{c}0.016^{* * *} \\
(0.002)\end{array}$ & \\
\hline Oil Revenues & & $\begin{array}{c}0.016^{* * *} \\
(0.002)\end{array}$ \\
\hline Ideology Dummy & $\begin{array}{c}-0.029^{* * *} \\
(0.002)\end{array}$ & $\begin{array}{c}-0.026^{* * *} \\
(0.002)\end{array}$ \\
\hline WTI x Ideo & $\begin{array}{l}-0.002 \\
(0.002)\end{array}$ & \\
\hline Oil x Ideo & & $\begin{array}{c}-0.005^{*} \\
(0.002)\end{array}$ \\
\hline Term FEs & $\checkmark$ & $\checkmark$ \\
\hline Topic controls & $\checkmark$ & $\checkmark$ \\
\hline Observations & 82,209 & 70,294 \\
\hline $\mathrm{R}^{2}$ & 0.034 & 0.034 \\
\hline
\end{tabular}

Table 4: Table reports coefficients from OLS models of voting consistent with the minister bloc at the deputy-vote level. Models include fixed effects and indicators for law topic (budget/fiscal, treaty, oil-related, or electoral) as indicated.

is trying to pass important or potentially controversial legislation, in order to ensure success or to demonstrate a show of strength with supermajority support. Similarly, the conditions at the beginning of a term may condition regime behavior. If a majority of elected deputies are policyseeking (i.e. ideological), the regime cannot efficiently buy them off using rents alone ${ }^{38}$ Instead, it may generate better behavior by offering policy concessions in the form of cabinet positions. We expect that the result will be a cabinet that roughly reflects the ideological composition of the legislature.

Figure 7 plots the proportion, by term, of ideological deputies and cabinet members. The two measures are relatively well-correlated $(r=0.5)$. In a democratic system with parliamentary

\footnotetext{
${ }^{38}$ This follows from the lower marginal returns on oil rents for such deputies.
} 
Figure 7: Ideological Representation in the Kuwaiti Cabinet and National Assembly.

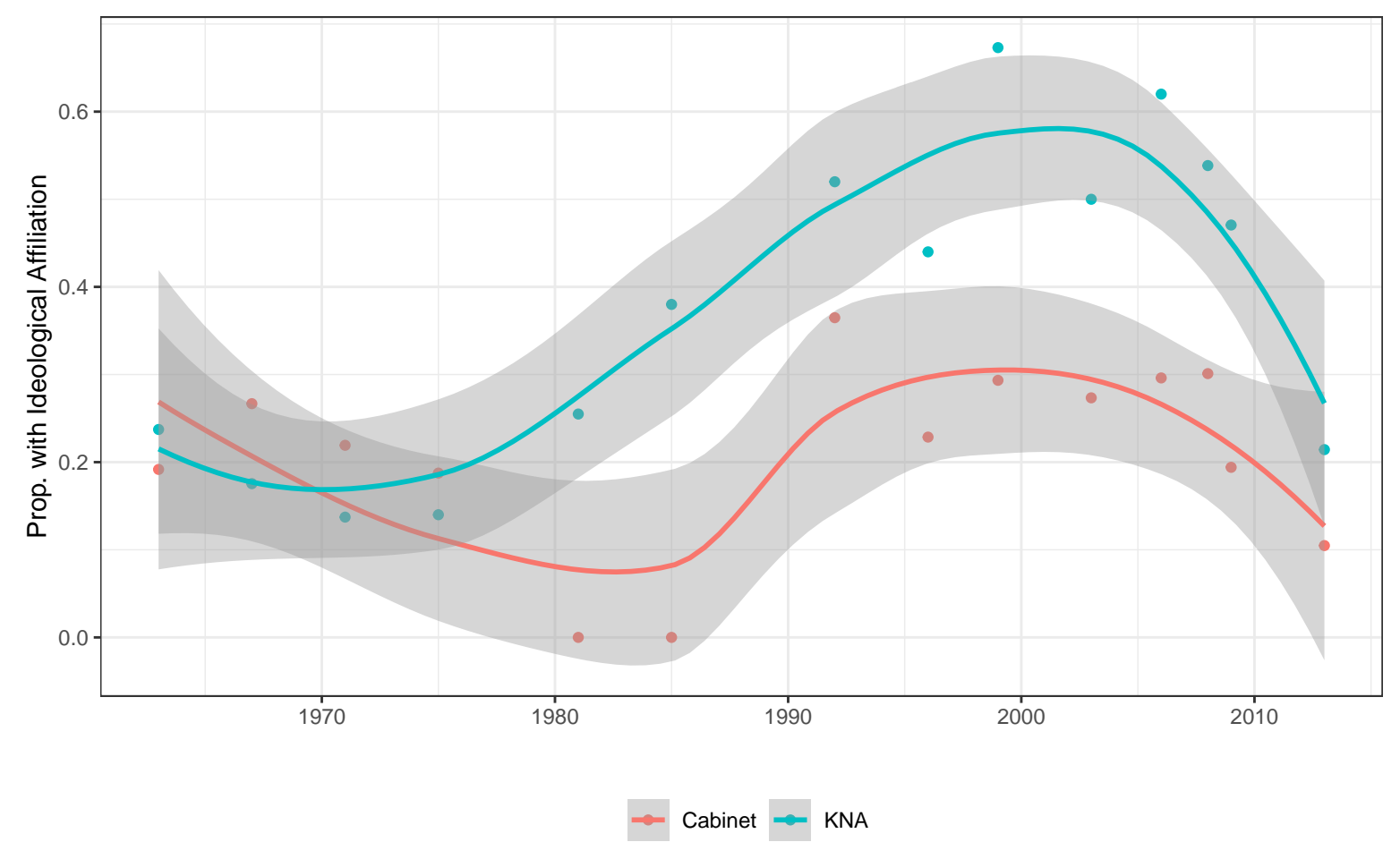

Note: Plot depicts the proportion of KNA deputies (blue) and cabinet members (red) with ideological affiliations by term, 1963-2013 (excludes the two short-lived assemblies elected in 2012). Source: Kuwait National Assembly Roll Call Votes (KNA-RCV) dataset.

institutions, this result would be wholly unremarkable: the government formed is generally expected to reflect the characteristics of the elected legislature. Yet in a system like Kuwait, this relationship is not so obvious. The Emir has sole discretion over cabinet appointments; he is in no way bound to select ministers based on the outcome of national elections. The observation that the proportion of ideologically-linked cabinet ministers is correlated with ideological representation in the legislature is an intriguing sign of responsiveness to electoral outcomes. This does not follow from institutional rules; we therefore propose that it demonstrates strategic behavior by the regime.

\section{Conclusion}

This article presents findings from a new dataset of roll call votes spanning the entire legislative history of Kuwait, an electoral authoritarian regime with a longstanding history of political opposition. Substantively, we find that 8 percent of roll call votes on passed laws involve elected deputies in the 
Kuwait National Assembly voting against the regime. We then use these data to empirically assess canonical assumptions central to cooptation theory, which we define as the intentional exchange of economic rents or policy concessions to rival elites in exchange for compliance with the autocrat's policy agenda. We find that a standard deviation increase in the availability of economic rents is associated with a 1.5 percentage point increase in cooperation with the regime. We also find that the addition of an affiliated cabinet member is associated with an expected 1.4 percentage point increase in cooperation with the regime. Though these findings suggest both economic rents and policy concessions facilitate cooperation with the regime, we find that they ineffective substitutes.

This article is not the first to explore the inner workings of legislatures in authoritarian contexts. Existing research has found that these institutions can respond to citizen needs Distelhorst \& Hou 2017, reflect citizen interests on non-sensitive issues (Truex 2016, and moderate protest and dissent Reuter \& Robertson 2015. But despite these important advances, less attention has been given to the question of how legislators behave in office and how the regime manages potential opposition. Data availability has long hampered efforts to study the internal operation of these bodies. With this project, we bring a rich new data source to bear on the question of legislator behavior in authoritarian regimes. Our findings underscore that this behavior is not entirely sycophantic. In addition to showing that a subset of laws pass in these contexts despite regime opposition, we find substantial variation in voting patterns at the individual level. Most importantly, we find evidence that proposed regime strategies of cooptation are effective in buying support from elected representatives on its policy agenda.

We see two promising pathways for further study that can build on these findings. First, a critical debate among scholars of authoritarian institutions revolves around whether these institutions function analogously to their democratic counterparts or whether they represent a wholly different form of politics Gandhi et al. 2020. Our findings suggest that both conceptions can be true within the same body. We find that executive coalition-building and related policy inclusion leads political outsiders to cooperate on policy: exactly the kind of compromise we would expect in a robust, representative legislature. Yet we also find evidence that the regime uses less aboveboard means - its vast fiscal resources - to generate the same cooperative spirit. This latter activity (with its presumed dependence on individual transfers in exchange for support) is wholly distinct from normative conceptions of democratic representation. If representation in these contexts is a 
real possibility, future research can aim to evaluate both its limits and the conditions under which authoritarian regimes will tolerate it.

Second, it remains an open question whether legislative opposition actually matters in authoritarian regimes with permissive institutions with law-making authority. In our study, we use a novel measure of opposition to provide evidence that it does: autocrats go to great (and costly) lengths to minimize its public presence in the legislature. Our findings indicate that positive inducements such as economic rents and policy concessions can facilitate the legislative cooperation autocrats require to achieve their policy goals. But more work is needed to understand the reverse, or the kinds of inducements that can effectively counter these tactics and encourage the development of more robust opposition. 


\section{References}

Al-Ghazali, S. M. (2007). Al-Jama'at al-Siyasiyya al-Kuwaitiyya fi Qarn 1910-2007: Al-Dusturiyyun - al-Islamiyyun - al-Shi'a - al-Qawmiyyun [Kuwaiti Political Groups from 1910-2007: Constitutionalists - Islamists - Shia - Nationalists]. Kuwait: n.p.

Al-Madaires, F. A. (1999). Al-Haraak al-Shi'i fi al-Kuwait [The Shia Movement in Kuwait]. Kuwait: Dar Qortas Publishing.

al Mdaires, F. A. (2010). Islamic Extremism in Kuwait: From the Muslim Brotherhood to Al-Qaeda and other Islamic Political Groups. London: Routledge.

Al-Nakib, F. (2014). Public Space and Public Protest in Kuwait, 1938-2012. City, 18(6), 723-734.

Al-Nakib, F. (2016). Kuwait Transformed: A History of Oil and Urban Life. Palo Alto: Stanford University Press.

Al-Shayeji, A. K. (1994). Intikhabat Majlis al-Umma al-Kuwaiti al-Sabi': Uktubr 1992 - Tahliil w-Nata'ij [The Seventh Kuwaiti National Assembly Elections: Analysis and Results]. Journal of the Gulf and Arabian Peninsula Studies, 19(72), 15-71.

Allarakia, L. A. (2016). Three Essays on the Dynamics of Legislatures in Monarchical Regimes: Kuwait's National Assembly. Ph.D., University of Houston, United States - Texas.

Assiri, A.-R. (1990). Kuwait's Foreign Policy: City-State in World Politics. Boulder, CO: Westview Press.

Azoulay, R. (2015). The Politics of Shi'i Merchants in Kuwait. In S. Hertog, G. Luciani, \& M. Valeri (Eds.), Business Politics in the Middle East (pp. 67-99). London: Hurst.

Baaklini, A. I. \& Abdul-Wahab, A. (1979). The Role of the National Assembly in Kuwait's Economic Development: National Oil Policy. In J. Smith \& L. D. Musolf (Eds.), Legislatures in Development: Dynamics of Change in New and Old States (pp. 311-333). Durham, NC: Duke University Press.

Baaklini, A. I., Denoeux, G., \& Springborg, R. (1999). Legislative Politics in the Arab World: The Resurgence of Democratic Institutions. Boulder: Lynne Rienner Publishers.

Beaugrand, C. (2017). Stateless in the Gulf: Migration, Nationality and Society in Kuwait. London: I.B. Tauris.

Blaydes, L. (2011). Elections and Distributive Politics in Mubarak's Egypt. Cambridge: Cambridge 


\section{University Press.}

Brancati, D. (2014). Democratic Authoritarianism: Origins and Effects. Annual Review of Political Science, 17(1), 313-326.

Burney, N. A., Mohaddes, K., Alawadhi, A., \& Al-Musallam, M. (2018). The Dynamics and Determinants of Kuwait's Long-run Economic Growth. Economic Modelling, 71, 289-304.

Crystal, J. (1992). Kuwait: The Transformation of an Oil State. London: Routledge.

Crystal, J. (1995). Oil and Politics in the Gulf: Rulers and Merchants in Kuwait and Qatar. Cambridge: Cambridge University Press.

Davenport, C. (2007). State Repression and Political Order. Annual Review of Political Science, $10(1), 1-23$.

Distelhorst, G. \& Hou, Y. (2017). Constituency Service under Nondemocratic Rule: Evidence from China. The Journal of Politics, 79(3), 1024-1040.

El-Katiri, L., Fattouh, B., \& Segal, P. (2013). Anatomy of an Oil-Based Welfare State: Rent Distrubution in Kuwait. In D. Held \& K. Ulrichsen (Eds.), The Transformation of the Gulf (pp. 183-205). London: Routledge.

Eltony, M. N. \& Al-Awadi, M. (2001). Oil Price Fluctuations and their Impact on the Macroeconomic Variables of Kuwait: A Case Study using a VAR Model. International Journal of Energy Research, 25(11), 939-959.

Frantz, E. \& Kendall-Taylor, A. (2014). A Dictator's Toolkit: Understanding How Co-optation affects Repression in Autocracies. Journal of Peace Research, 51(3), 332-346.

Freer, C. (2018). Rentier Islamism: The Influence of the Muslim Brotherhood in Gulf Monarchies. Oxford: Oxford University Press.

Gandhi, J. (2008). Political Institutions under Dictatorship. Cambridge: Cambridge University Press.

Gandhi, J., Noble, B., \& Svolik, M. (2020). Legislatures and Legislative Politics Without Democracy. Comparative Political Studies, 53(9), 1359-1379.

Gandhi, J. \& Przeworski, A. (2006). Cooperation, Cooptation, and Rebellion Under Dictatorships. Economics and Politics, 18(1), 1-26.

Ghabra, S. (1993). Kuwait: Elections and Issues of Democratization in a Middle Eastern State. Digest of Middle East Studies, 2(2), 1-27. 
Ghabra, S. (1997a). Balancing State and Society: The Islamic Movement in Kuwait. Middle East Policy, 5(2), 58-72.

Ghabra, S. (1997b). Kuwait and the Dynamics of Socio-Economic Change. Middle East Journal, $51(3), 358-372$.

Herb, M. (2002). Democratization in the Arab World? Emirs and Parliaments in the Gulf. Journal of Democracy, 13(4), 41-47.

Herb, M. (2016). The Origins of Kuwait's National Assembly. London School of Economics and Political Science, Kuwait Programme Paper Series, 39.

Jamal, A. Y. (2005). Lamahat min Tarikh al-Shi'a fi al-Kuwait: Min Nashat al-Kuwait ila al-Istiqlal [Glimpses of the History of the Shia in Kuwait: From the Emergence of Kuwait to Independence] (1st ed.). Kuwait: Dar Al-Nabaa.

Jensen, N. M., Malesky, E., \& Weymouth, S. (2014). Unbundling the Relationship between Authoritarian Legislatures and Political Risk. British Journal of Political Science, 44(3), 655-684.

Khalaf, J. M. (1984). The Kuwait National Assembly: A Study of its Structure and Function. Ph.D., State University of New York at Albany, United States - New York.

Kraetzschmar, H. (2018). In the Shadow of Legality: Proto-Parties and Participatory Politics in the Emirate of Kuwait. In F. Cavatorta \& L. Storm (Eds.), Political Parties in the Arab World: Continuity and Change (pp. 230-251). Oxford: Oxford University Press.

Longva, A. N. (1999). Walls Built On Sand: Migration, Exclusion, And Society In Kuwait. Boulder, CO: Westview Press.

Louër, L. (2011). Transnational Shia Politics: Religious and Political Networks in the Gulf. London: Hurst Publishers. Google-Books-ID: B8wnEtH8oDgC.

Malesky, E. \& Schuler, P. (2010). Nodding or Needling: Analyzing Delegate Responsiveness in an Authoritarian Parliament. American Political Science Review, 104(3), 482-502.

McMillan, J. \& Zoido, P. (2004). How to Subvert Democracy: Montesinos in Peru. Journal of Economic Perspectives, 18(4), 69-92.

Pall, Z. (2020). The Development and Fragmentation of Kuwait's al-Jama'a al-Salafiyya: Purity over Pragmatism. The Middle East Journal, 74(1), 9-29.

Regnier, E. (2007). Oil and Energy Price Volatility. Energy Economics, 29(3), 405-427.

Reuter, O. J. \& Robertson, G. B. (2015). Legislatures, Cooptation, and Social Protest in Contem- 
porary Authoritarian Regimes. The Journal of Politics, 77(1), 235-248.

Ross, M. L. (2012). The Oil Curse: How Petroleum Wealth Shapes the Development of Nations. Princeton: Princeton University Press.

Salih, K. O. (1992). The 1938 Kuwait Legislative Council. Middle Eastern Studies, 28(1), 66-100.

Salih, K. O. (2006). Parliamentary Control of the Executive: Evaluation of the Interpellation Mechanism, Case Study Kuwait National Assembly, 1992-2004. Journal of South Asian and Middle Eastern Studies, 29(3), 36-69.

Shalaby, M. (2015). Women's Political Representation in Kuwait: An Untold Story. Rice University, James A. Baker III Institute for Public Policy, Women's Rights in the Middle East Program.

Smith, S. C. (1999). Kuwait, 1950-1965: Britain, the Al-Sabah, and Oil. Oxford: Oxford University Press.

Stacher, J. (2012). Adaptable Autocrats: Regime Power in Egypt and Syria. Palo Alto: Stanford University Press.

Svolik, M. W. (2012). The Politics of Authoritarian Rule. Cambridge: Cambridge University Press.

Szakonyi, D. (2018). Businesspeople in Elected Office: Identifying Private Benefits from Firm-Level Returns. American Political Science Review, 112(2), 322-338.

Takriti, A. R. (2018). Political Praxis in the Gulf: Ahmad al-Khatib and the Movement of Arab Nationalists, 1948-1969. In J. Hanssen \& M. Weiss (Eds.), Arabic Thought against the Authoritarian Age: Towards an Intellectual History of the Present (pp. 86-112). Cambridge: Cambridge University Press.

Tetreault, M. A. (1991). Autonomy, Necessity, and the Small State: Ruling Kuwait in the Twentieth Century. International Organization, 45(4), 565-591.

Truex, R. (2016). Making Autocracy Work: Representation and Responsiveness in Modern China. Cambridge: Cambridge University Press.

Ulrichsen, K. C. (2014). Politics and Opposition in Kuwait: Continuity and Change. Journal of Arabian Studies, 4(2), 214-230.

Wintrobe, R. (1998). The Political Economy of Dictatorship. Cambridge: Cambridge University Press.

Zaccara, L. (2013). Comparing Elections in Gulf Cooperation Council Countries after the Arab Spring: The United Arab Emirates, Oman, and Kuwait. Journal of Arabian Studies, 3(1), 
$80-101$.

Zahlan, R. S. (1998). The Making of the Modern Gulf States: Kuwait, Bahrain, Qatar, the United Arab Emirates and Oman. Ithaca: Ithaca Press. 


\section{Supplementary Materials}

The Supplementary Materials appendix includes the following items:

1. S.1: Data Collection

(a) Figure A.1. Sample transcript

(b) Figure A.2 Qualtrics screenshot

(c) Table A.1: Data collection and coding summary

2. S.2. Descriptive Statistics

(a) Figure A.3 Cooperation by law topic

3. S.3: Policy Concessions

4. S.4: Additional Analysis 


\section{S.1 Data Collection}

The Kuwait National Assembly Roll Call Votes dataset includes recorded roll call votes for each law passed by the KNA from 1963 to 2016. In this section, we describe the procedures we used to collect these data in detail.

The Kuwait National Assembly Online Archive includes a list of each law passed by the Kuwait National Assembly (KNA) since 1963. The online archive makes public a searchable list of these laws, which include supplemental data describing the date and legislative term in which the law was passed. The Archive also includes digitized .pdf files of legislative transcripts that include the minutes of meeting of the KNA since 1963. These legislative transcripts are colloquially referred to as "minutes" (madbața, pl. mad̄ābit) in Kuwait. The full archive consists of 551,605 .pdf pages across 2,294 .pdf files. There have been 2,188 unique days when the KNA has met. Because the .pdf files are often quite large, some are broken up into multiple files. In sum, the KNA has passed 3,595 laws 1963 to 2016 .

Using data on laws and when they were passed, we were able to locate the point of final deliberation and voting for each law within the set of legislative transcripts. These legislative transcripts record roll call votes for each "second deliberation," or final vote on a law or group of laws, including the vote choice of all MPs and ministers present. Figure A.1 shows sample pages from one of these transcripts, including the final vote record. In order to code each of these votes, we hired a team of research assistants to search the KNA transcripts to find the exact location of each roll call vote. We identified complete roll call votes for 3,337 laws (93 percent). As groups of laws can be voted on concurrently, the full dataset includes includes 2,693 "second deliberation" votes. 
Figure A.1: Sample transcript
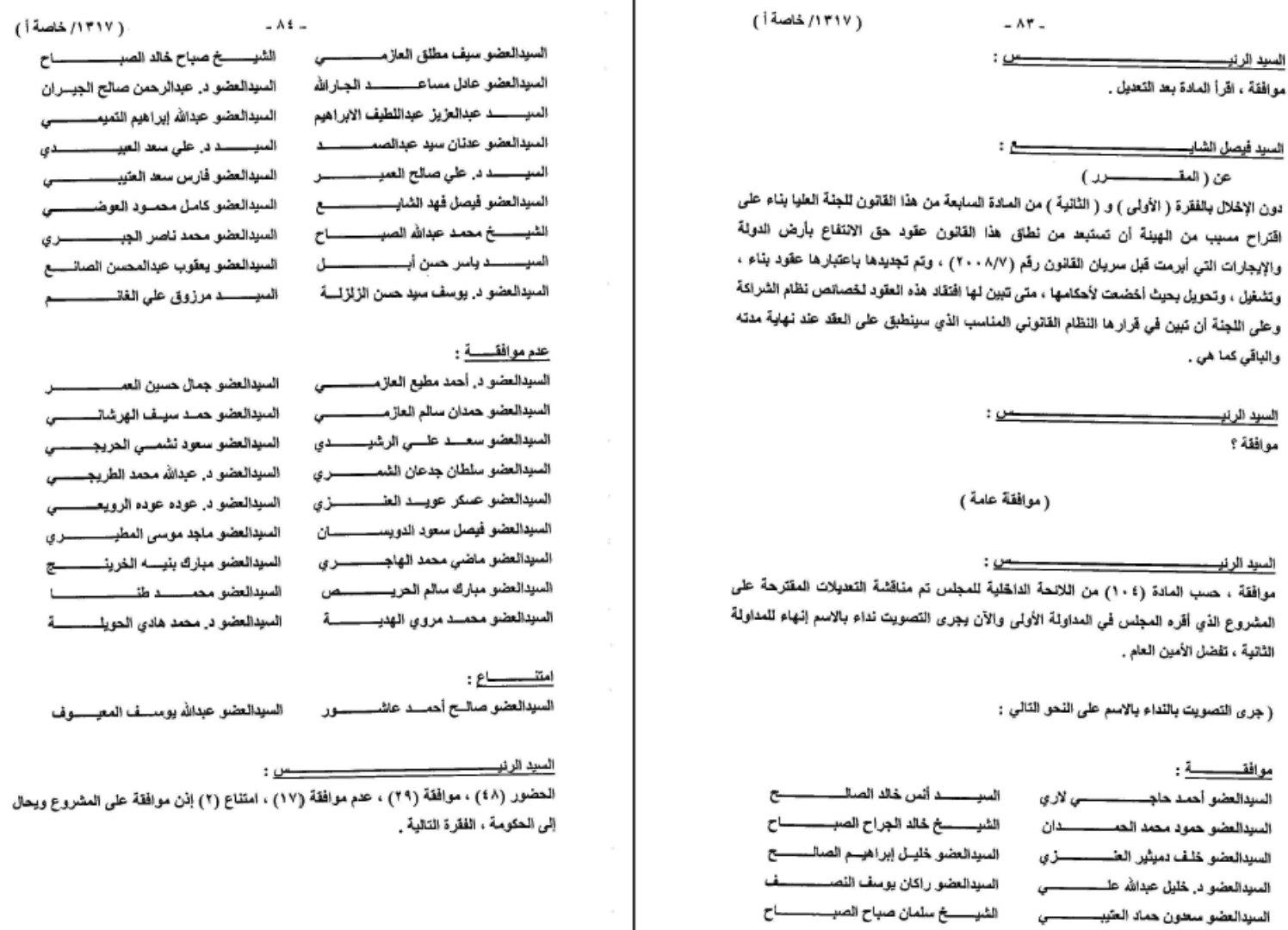

Note: The above transcript includes the roll call votes recorded on June 30, 2014, for Law No. 116 of 2014 on

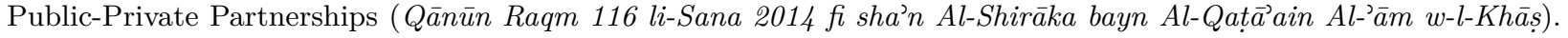
Source: Kuwait National Assembly Archive.

We then hired a team of research assistants to assist with the coding of each law. To do this, we created a unique qualtrics form for each of the 16 legislative terms included in our analysis. The platform asked the coders to find the pages where the roll call vote appear, describe the vote in some detail, and identity whether a minister voted yes, no, or abstain for the law. Often in the transcripts, once a law is passed, the speaker of the KNA describes the total number of individuals who voted yes, no, or abstain. The speaker also announces the number of individuals present and absent. Coders were asked to record these numbers where they appeared. A partial screenshot of one of the forms we used is shown in Figure A.2. 
Figure A.2: Qualtrics screenshot

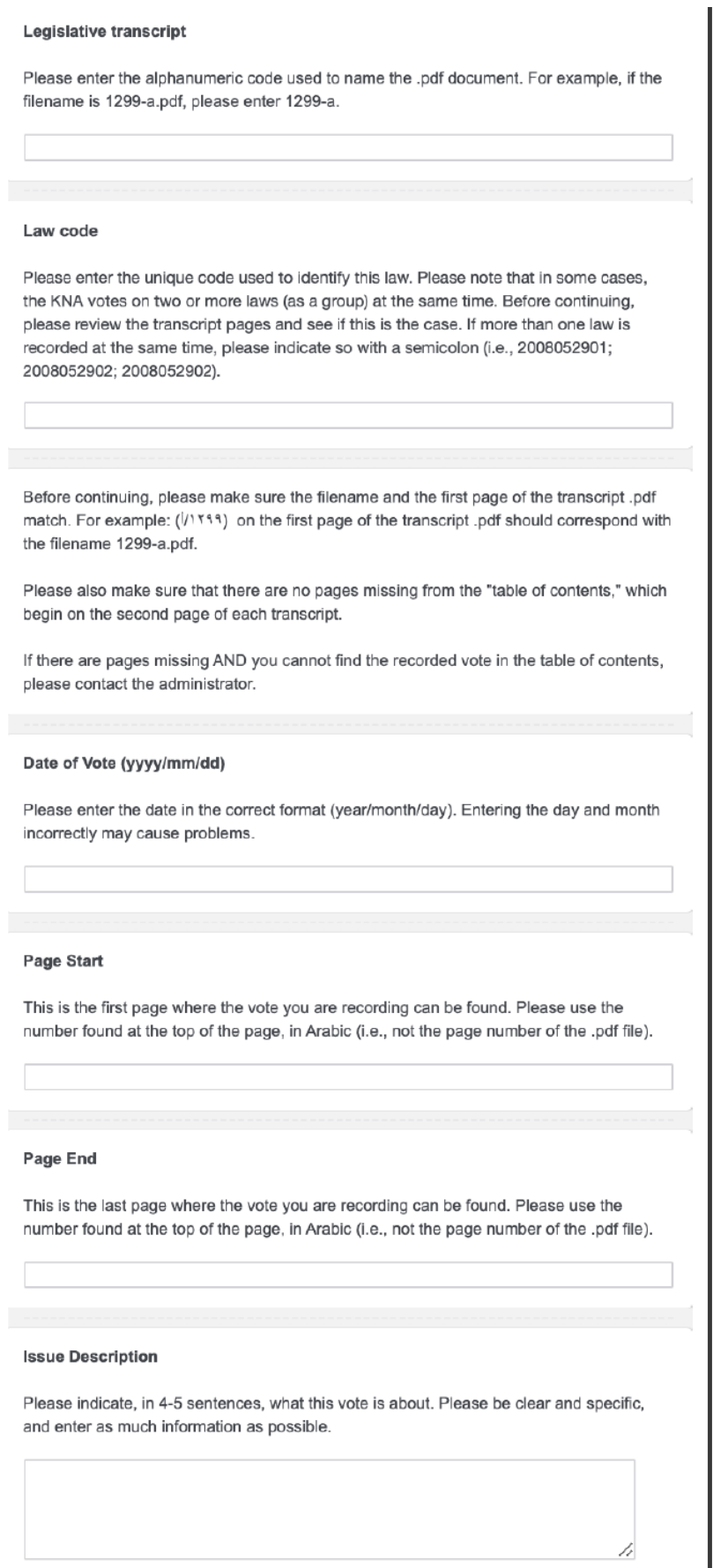

Votes

When you reach the pdf page in the transcript where the roll call votes are listed, please read the names listed on the .pdf first. The process will take longer if you read the form first, and then try to find the names on the .pdf. As you see each name on the .pdf, find them listed (in alphabetical order) on the form below and click "yes," "no," or "abstain."

Generally, names are listed in both the .pdf and the form in alphabetical order by first name. This may not always be the case

If, for some reason, you come across a name in the .pdf that is not listed in this form, please enter that name in the Notes section, as well as the individual's vote (i.e., "yes," "no," "abstain").

Ministers have been highlighted in gray. MPs selected as Ministers have not been highlighted.

If for some reason the names of individual MPs and Ministers were not recorded for this vote, please mention this in the Notes section.

Please also describe exactly how many individuals voted "yes," "no," or "abstain." This will usually appear immediately after the votes are recorded. All proposals to be considered as laws are recorded by roll call, meaning that every law in the laws spreadsheet should have a corresponding roll call vote.

\begin{tabular}{|c|c|c|c|}
\hline & yes & no & abstain \\
\hline الشيخ احد الحصرد الجابر -- . & $\square$ & $\square$ & $\square$ \\
\hline احمد خالك الكليب -- 10لا & $\square$ & $\square$ & $\square$ \\
\hline لــ احد عبدالثل الريعى -- 8/. & $\square$ & $\square$ & $\square$ \\
\hline د. احمد محمد الخطيب -- 9 & $\square$ & $\square$ & $\square$ \\
\hline احمد معد صلالح العنسانى -- , & $\square$ & $\square$ & $\square$ \\
\hline احد معد النصار -- 3 & $\square$ & $\square$ & $\square$ \\
\hline اهمد نصنار الثريعان -- 19 & $\square$ & $\square$ & $\square$ \\
\hline الحد يعقوب باهز -- 5 & $\square$ & $\square$ & $\square$ \\
\hline د. اسماعيل خضر الثططي -- 8 & $\square$ & $\square$ & $\square$ \\
\hline تركى محد للعزم -- 24 & $\square$ & $\square$ & $\square$ \\
\hline جلسم حعد الصعر -- 3 & $\square$ & $\square$ & $\square$ \\
\hline جلسم محد العون -- 7 لو & $\square$ & $\square$ & $\square$ \\
\hline جمل احد الكنري -- 13 & $\square$ & $\square$ & $\square$ \\
\hline جمعان فلح للعازمي -- 23/لا & $\square$ & $\square$ & $\square$ \\
\hline حببب جوهر حهات -- و & $\square$ & $\square$ & $\square$ \\
\hline حمد عبداثل الجرعان -- 2 & $\square$ & $\square$ & $\square$ \\
\hline حمود ناصر الجيري -- 14 & $\square$ & $\square$ & $\square$ \\
\hline خالد سالم علره ... 21 & $\square$ & $\square$ & $\square$ \\
\hline خلت دمئر العزي -- 18 & $\square$ & $\square$ & $\square$ \\
\hline رائد سلمان الهيبدة -- 18 & $\square$ & $\square$ & $\square$ \\
\hline سالم عبدالة. الحماد -- 12 & $\square$ & $\square$ & $\square$ \\
\hline سو المشخ سع العبدالة السائم الصباح -- . & $\square$ & $\square$ & $\square$ \\
\hline سع بليق العازمي -- 25 & $\square$ & $\square$ & $\square$ \\
\hline الشيخ سعود ناصر الصباح -- و & $\square$ & $\square$ & $\square$ \\
\hline شنارع ناصر العجمي -- 21 & $\square$ & $\square$ & $\square$ \\
\hline صلع يوسث الفضلة -- 10 & $\square$ & $\square$ & $\square$ \\
\hline الشبخ صباح الاحمد الجبابر --. ر & $\square$ & $\square$ & $\square$ \\
\hline ضاري عبالثه العُّان -- و & $\square$ & $\square$ & $\square$ \\
\hline
\end{tabular}

Note: The above Qualtrics screenshot is a partial depiction of the platform used by coders to record roll call votes in the seventh legislative term (1992-1996).

Table 2 summarizes the data we collected for each legislative term. Each legislative term from 1963 to 2016 is included in the database. Because two of these terms were declared "void" (2012_1 
and 2012_2), they are not assigned numbers by the Kuwait National Assembly. The coding process began on 22 January 2019 and ended on 23 February 2020.

Table A.1: Data collection and coding summary

\begin{tabular}{cccccccc}
\hline \hline Term & Years & Votes & Laws & Missing & Transcripts & Start & End \\
\hline 1 & $1963-1966$ & 10,213 & 195 & $16(0.08)$ & 228 & $2019-11-04$ & $2020-01-20$ \\
2 & $1967-1970$ & 8,663 & 170 & $26(0.15)$ & 203 & $2019-12-30$ & $2020-01-16$ \\
3 & $1971-1975$ & 7,011 & 132 & $18(0.14)$ & 237 & $2020-01-20$ & $2020-02-04$ \\
4 & $1975-1976$ & 5,760 & 98 & $7(0.07)$ & 107 & $2020-02-06$ & $2020-02-23$ \\
5 & $1981-1985$ & 36,908 & 703 & $83(0.12)$ & 219 & $2019-09-09$ & $2019-10-14$ \\
6 & $1985-1986$ & 6,052 & 103 & $0(0.00)$ & 92 & $2019-02-13$ & $2019-03-13$ \\
7 & $1992-1996$ & 43,295 & 820 & $66(0.08)$ & 243 & $2019-07-01$ & $2019-09-10$ \\
8 & $1996-1999$ & 8,001 & 128 & $0(0.00)$ & 181 & $2019-04-03$ & $2019-05-08$ \\
9 & $1999-2003$ & 14,459 & 335 & $1(0.00)$ & 218 & $2019-05-28$ & $2019-07-01$ \\
10 & $2003-2006$ & 6,925 & 166 & $16(0.10)$ & 158 & $2019-06-09$ & $2019-06-19$ \\
11 & $2006-2008$ & 3,753 & 97 & $7(0.07)$ & 69 & $2019-04-23$ & $2019-05-13$ \\
12 & $2008-2009$ & 516 & 20 & $2(0.10)$ & 35 & $2019-10-17$ & $2019-10-17$ \\
13 & $2009-2011$ & 4,013 & 105 & $7(0.07)$ & 118 & $2019-04-08$ & $2019-05-17$ \\
$2012 \_1$ & $2012-2012$ & 260 & 4 & $0(0.00)$ & 29 & $2019-10-16$ & $2019-10-16$ \\
$2012 \_2$ & $2012-2013$ & 2,532 & 129 & $0(0.00)$ & 35 & $2019-03-18$ & $2019-03-21$ \\
14 & $2013-2016$ & 10,113 & 390 & $9(0.02)$ & 122 & $2019-01-22$ & $2019-02-21$ \\
\hline Total & $1963-2016$ & 168,474 & 3,595 & $258(0.07)$ & 2,294 & $2019-01-22$ & $2020-02-23$ \\
\hline
\end{tabular}

Note: Table displays the total number of laws passed by the KNA in each legislative term. Missing denotes the number of laws (and the percent of the total) that were not found in the transcripts in each term. Transcripts denotes the number of legislative transcripts (.pdf files) archived by the Kuwait National Assembly Online Archive in each legislative term. Start and End refer to the start and end dates of the coding process for each term, respectively. Source: Kuwait National Assembly Roll Call Votes (KNA-RCV) dataset. 


\section{S.2 Descriptive Statistics}

Figure A.3: Cooperation by law topic

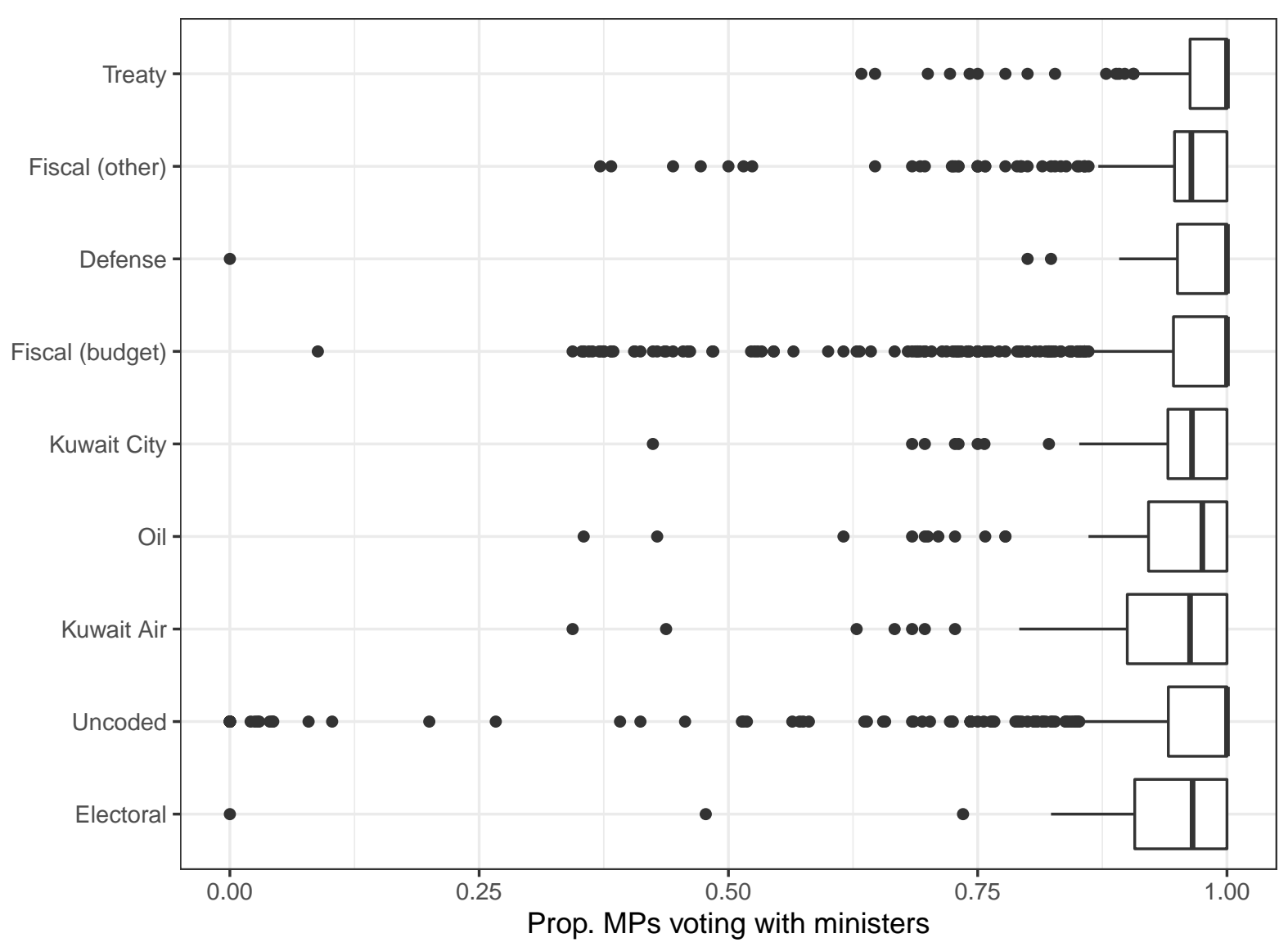

Note: Figure plots the proportion of deputies voting with ministers by law topic. Topics are listed in descending order of average cooperation. The unit of analysis is the second deliberation vote. 


\section{S.3 Policy Concessions}

Much of the existing literature on cooptation has shown that the incorporation of political parties in autocratic legislatures makes the exchange of concessions more credible, reducing incentives to rebel and extending the survival of incumbent autocrats Gandhi \& Przeworski 2006 Gandhi 2008 Frantz \& Kendall-Taylor 2014. Though formal political parties do not exist in the Kuwait context, since 1963, elected deputies have tended to affiliate with one of six political factions, or "protoparties": the Muslim Brotherhood, Salafis, independent Islamists, National-liberals, Shia Islamists, and left-populists. In this section, we briefly describe each of these groups and provide several examples of the types of concessions these groups advocate for.

\section{S.3.1 Muslim Brotherhood}

Kuwait is home to the oldest and most organized Muslim Brotherhood branch among the Arab Gulf states. The Kuwait branch emerged in 1951, a full decade before independence. Like its counterpart in Egypt, the Brotherhood initially sought the "Islamization" of society and focused its work on reforming the education sector and expanding its charitable activities. Throughout the 1960s and 1970s, Brotherhood members served as ministers of Religious Endowments and Islamic Affairs, Justice, and Oil. Throughout this period, the ruling family provided limited concessions to the Muslim Brotherhood in an effort to weaken the appeal of Arab Nationalists in the National Assembly. The Brotherhood used its influence to pressure the ruling family to implement sharia, or Islamic, law with varying degrees of success. Specifically, the Brotherhood unsuccessfully argued for an amendment to Article 2 of the Constitution that would proclaim sharia "the" rather than “a" primary source of legislation (Freer 2018 pp. 53).

In the 1980s, the Brotherhood sought to ban Christmas celebrations and succeeded in limiting nationality to Muslims and banning the consumption or sale of alcohol in embassies. During this period, the Brotherhood consolidated control over several government financial institutions: the World Islamic Charity Body, Zakat House, and Kuwait Finance House (Freer 2018, pp. 75). After the liberation of Kuwait, the Muslim Brotherhood announced the creation of a political organization, the Islamic Constitutional Movement (ICM), that continued to advocate for shariah.

When women were granted the right to vote in 2005 (against the wishes of ICM-affiliated elected 
deputies), the organization pushed to ensure the measure complied with the principles of shariah by creating separate polling locations for women 39 .

\section{S.3.2 Salafis}

Salafism emerged in Kuwait in the 1960s with the arrival of several Saudi-trained preachers who began working with the Muslim Brotherhood. By the 1970s, Salafis left the Brotherhood and began forming their own, smaller organizations due to ideological and doctrinal disagreements Pall 2020. The ruling family capitalized on this rift and provided Salafis with financial support to create a charity similar to the Muslim Brotherhood. Salafis used their growing support in the National Assembly to advocate for a variety of Islamist-inspired policies. Following the 1992 election, for example, several elected deputies unsuccessfully sought to establish an "authority to direct the public to do good and refrain from evil," which would effectively function as an Islamic religious police Al-Shayeji 1994 Ghabra 1997a). When a reformed press law was passed in 2006, Salafis forced the inclusion of a prohibition on directly insulting God, the prophets, and Islam Freer 2018. pp. 110).

Though Salafis were not as cohesively organized as the Brotherhood, their political organizationthe Popular Islamic Gathering - sought to challenge the Brotherhood's control over the Islamic sector. This was particularly the case as Salafis sought greater control over the Ministry of Religious Endowments and Islamic Affairs, especially after the events of the Arab Spring. In 2014, a prominent Salafi elected deputy was given ministerial control over the Ministry of Public Works and the Ministry of Oil. For example, during this period, Salafi influence over the Ministry of Religious Endowments and Islamic Affairs allowed it to channel funds to Cambodian and Indonesian Salafis with ties to Kuwaiti Salafis (Pall 2020, pp. 23).

\section{S.3.3 Independent Islamists}

The rise of Islamism in the 1980s resulted in the emergence of a new class of Islamist actors unaffiliated with the Muslim Brotherhood or the Salafis. In the Kuwait context, these Islamists are referred to as "independent Islamists." These Islamists do not operate under the direction of or with support from a political or party-like organization. Electorally, these Islamists do at

\footnotetext{
${ }^{39}$ See: https://carnegieendowment.org/sada/21635
} 
times coordinate with both Muslim Brotherhood and Salafi competitors in an effort to limit votesplitting. In the National Assembly, however, these Islamist deputies do coordinate and have in the past joined broader Islamist voting blocs in the legislature. These elected deputies also support efforts to implement shariah-compliant legislation. Throughout the 1990s and 2000s, independent Islamists periodically controlled the Ministry of Religious Endowments and Islamic Affairs.

\section{S.3.4 National-liberal}

National-liberals trace their origins to the Kuwait branch of the Movement of Arab Nationalists, led by Dr. Ahmad Khatib: the leader of Kuwait's first "opposition." Much of the success of Arab Nationalism can be attributed to the rise of Nasserism and anti-colonial sentiment in Kuwait before independence (Takriti 2018). When the National Assembly first convened in 1963, Arab Nationalists were most interested in using the National Assembly to vocalize support for transnational causes important to the larger movement. But they also used the National Assembly to limit the ruling family's absolute control over the newly independent state bureaucracy. In 1964, Arab Nationalists successfully objected to the appointment of six prominent merchants to the Council of Ministers, on the grounds that merchant inclusion in the cabinet constituted a conflict of interest. In 1965, the Council of Ministers introduced restrictive laws allowing the Minister of Information to close publications and monitor civil associations and clubs. In response, eight elected deputies close to the movement resigned Crystal 1995, pp. 87-88). From 1973 to 1975, the movement was critical to the successful nationalization of Kuwait's oil industry (Baaklini \& Abdul-Wahab 1979).

With waning support for Arab Nationalism across the region, the movement reconstituted itself in the 1980s and 1990s under the auspices of a broader liberal agenda. This agenda centered on the expansion and protection of civil and political rights Al-Ghazali 2007). These efforts included support for women's rights, particularly the right to vote and run in National Assembly elections. In 2006, liberals (as well as Islamists) successfully advocated for a reform to Kuwait's longstanding electoral law, resulting in a change from 25 electoral districts to five.

\section{S.3.5 Leftist-populist}

In 1999, a left-leaning coalition of several liberal, tribal, and Shia elected deputies announced the creation of the Popular Action Bloc. Broadly, leftist-populists in the Kuwait context have advocated 
for policies and legislation focused on social justice, economic equality, and national independence

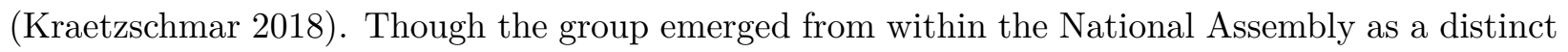
voting bloc, it participated in subsequent elections as an electoral front with a diverse following. Because the Popular Action Bloc cast itself as "true" parliamentary opposition, from 1999 to 2008, its members refused to join the Council of Ministers. The group introduced and advocated for legislation that resonated with traditional liberal causes, such as the protection of press freedoms and the expansion of laws protecting the right to assemble Al-Ghazali 2007. In 2001, for example, the group advocated for a "freedoms session" in the National Assembly. Fearing the session would be used to create a formal political parties law, the government boycotted the session 40 . On other occasions, these deputies have also advocated for various populist causes, such as the cancelation of interest on bank loans 41

\section{S.3.6 Shia Islamists}

Shia comprise roughly $25 \%$ of the citizen population of Kuwait. Historically, Kuwaiti Shia have been divided along ethnic lines: Arab Shia are those whose ancestors migrated from Saudi Arabia, Bahrain, and, to a lesser extent, southern Iraq. Iranian Shia are those who migrated to Kuwait in the nineteenth century from Southern Iran Jamal 2005, al Mdaires 2010 Louër 2011. Since the 1980s, various Shia Islamist groups have participated in National Assembly elections. Though not explicitly ethno-sectarian, these groups have run under associational labels that signal their connection to various Shia clerics in Iraq, Lebanon, and Iran. These groups have occasionally allied with Sunni Islamist groups (such as the Muslim Brotherhood and the Salaf) on issues related to sharia law Al-Madaires 1999. But, more broadly, their advocacy has focused more directly on expanding protections for Kuwait's Shia minority. Since their rise in the 1980s, these groups have used the National Assembly to institutionalize these protections in legislation and through legislative advocacy. These include recognition of independent personal status courts, an expansion of the number of Shia places of worship (such as hussainiyat, or congregation halls for Shia religious ceremonies), permits for Shia newspapers, recognition of Ashura as a national holiday, and the naming of schools and other public buildings with the names of Shia leaders Al-Ghazali 2007.

\footnotetext{
${ }^{40}$ See: https ://www .albayan.ae/one-world/2001-04-09-1.1172346.

${ }^{41}$ See: https://riskandforecast.com/post/kuwait/drama-in-kuwaiti-parliament_532.html
} 


\section{S.4 Additional Analyses}

\section{S.4.1 Probit Specifications}

Here we report output from probit specifications of the models in A.2 testing hypotheses 1 and 2.

\begin{tabular}{|c|c|c|c|c|c|c|}
\hline & \multicolumn{6}{|c|}{ Dependent variable: } \\
\hline & \multicolumn{6}{|c|}{ Voting with regime } \\
\hline & (1) & $(2)$ & $(3)$ & (4) & $(5)$ & $(6)$ \\
\hline WTI Price & $\begin{array}{c}0.127^{* * *} \\
(0.018)\end{array}$ & $\begin{array}{c}0.151^{* * *} \\
(0.020)\end{array}$ & & & & \\
\hline Cabinet Affiliate & & & & & $\begin{array}{c}0.104^{* * *} \\
(0.015)\end{array}$ & $\begin{array}{c}0.036 \\
(0.022)\end{array}$ \\
\hline Ideology Dummy & & & & & $\begin{array}{c}-0.313^{* * *} \\
(0.022)\end{array}$ & $\begin{array}{c}-0.111^{*} \\
(0.057)\end{array}$ \\
\hline Oil Revenues & & & $\begin{array}{c}0.125^{* * *} \\
(0.020)\end{array}$ & $\begin{array}{c}0.158^{* * *} \\
(0.022)\end{array}$ & & \\
\hline Term FEs & $\checkmark$ & $\checkmark$ & $\checkmark$ & $\checkmark$ & $\checkmark$ & $\checkmark$ \\
\hline MP FEs & & $\checkmark$ & & $\checkmark$ & & $\checkmark$ \\
\hline Topic controls & $\checkmark$ & $\checkmark$ & $\checkmark$ & $\checkmark$ & $\checkmark$ & $\checkmark$ \\
\hline Observations & 82,209 & 82,209 & 70,294 & 70,294 & 82,209 & 82,209 \\
\hline
\end{tabular}

Table A.2: Cooptation strategy and voting with the regime. Table reports coefficients from probit models of voting consistent with the minister bloc at the deputy-vote level. All models include term fixed effects and indicators for law topic (budget/fiscal, treaty, oil-related, or electoral). Models alternately include controls for legislator attributes (age, gender, education, sect, occupation, and tribal affiliation) or legislator fixed effects. WTI price and oil revenues are standardized continuous variables. 